\title{
Montessori Method in Early Childhood Education: A Systematic Review Işıl KIRAN ${ }^{\mathrm{a}^{*}}$ (ORCID ID - 0000-0002-4589-5093) \\ Bilal MACUN ${ }^{\text {b }}$ (ORCID ID - 0000-0001-2025-5807) \\ Yusuf ARGIN ${ }^{c}$ (ORCID ID - 0000-0003-2557-9808) \\ ilkay ULUTAŞ ${ }^{d}$ (ORCID ID - 0000-0002-2234-0773) \\ ${ }^{a}$ Millî Eğitim Bakanlığı, Ankara/Türkiye \\ ${ }^{b}$ Ağrı İbrahim Çeçen Üniversitesi, Eğitim Fakültesi, Ağrı/Türkiye \\ c Sinop Üniversitesi, Türkeli Meslek Yüksek Okulu, Sinop/Türkiye \\ ${ }^{d}$ Gazi Üniversitesi, Gazi Eğitim Fakültesi, Ankara/Türkiye
}

\section{Article Info}

\section{DOI: $10.14812 /$ cufej.873573}

Article history:

Received 03.02.21

Revised $\quad 11.08 .21$

Accepted 20.08.21

Keywords:

Montessori,

Systematic review,

Preschool,

Montessori Method.

\begin{abstract}
The aim of this study was to examine the researches on the Montessori method in the field of early childhood education in Turkey and to analyze the studies conducted until April 2020, without any starting date limitation, according to the study group, the pattern, the year of publication, the data collection tools used, the purposes and the subjects studied. 22 articles were analyzed within the scope of the research. There are 15 articles using quantitative research method, 6 articles using qualitative research method and 1 article using mixed research method in the analyzed studies. The samples of the studies were grouped under four headings as child, teacher, teacher candidate and family. It was observed that 16 out of 22 articles examined in the study used a scale or test whose validity and reliability were made, an interview form in 5 studies and an observation report in one study. Most of the studies conducted as quantitative researches and the used scales have shown that the studies are resultoriented not process-oriented. In the study, it was observed that the studies on the Montessori approach were more in $2019(n=7)$ and $2016(n=6)$ compared to other years. Research results showed that researches focus more on visual perception and cognitive development. Studies can be made on all areas of child development rather than focusing on a few areas, and the Montessori approach applied in Turkey can be evaluated with a general view. It is expected that this research will contribute to the determination of the gaps in the field related to the Montessori method.
\end{abstract}

\section{Erken Çocukluk Eğitiminde Montessori Yöntemi:}

\section{Bir Sistematik Derleme}

\begin{tabular}{ll}
\hline Makale Bilgisi \\
\hline DOI: $10.14812 /$ cufej.873573 \\
\hline Makale & Geçmişi: \\
Geliş & 03.02 .21 \\
Düzeltme & 11.08 .21 \\
Kabul & 20.08 .21 \\
\hline
\end{tabular}

Öz

Bu çalışmanın amacı, Türkiye'de erken çocukluk eğitimi alanında Montessori yöntemi ile ilgili yapılan araştırmaları incelemek ve başlangıç tarihi sınırlaması olmaksızın Nisan 2020 yılına kadar yapılmış araştırmaları çalışma grubu, deseni, yayın yılı, kullanılan veri toplama araçları, amaçları ve araştırılan konulara göre analiz etmektir. Araştırma kapsamında toplam 22 makale analiz edilmiştir. İncelenen çalışmalarda nicel araştırma yöntemi kullanılan 15 makale, nitel araştırma yöntemi kullanılan 6 makale ve karma araştırma yöntemi kullanan bir makale bulunmaktadır. İncelenen çalışmaların örneklemleri çocuk, öğretmen, öğretmen adayı ve aile olmak üzere dört başlık altında

*Author: isil.kiran@meb.gov.tr 
Kıran, Macun, Argın \& Ulutaş - Çukurova Üniversitesi Eğitim Fakültesi Dergisi, 50(2), 2021, 1154-1183

Anahtar Kelimeler:

Montessori,

Sistematik derleme,

Okul öncesi,

Montessori yöntemi. toplanmıştır. Araştırmada incelenen 22 makaleden 16 'sında geçerlik ve güvenirliği yapılmış olan bir ölçek veya test, beş çalışmada görüşme formu ve bir çalışmada ise gözlem raporu kullanıldığı görülmüştür. Yapılan çalışmaların çoğunluğu nicel araştırma olarak desenlenmiş ve kullanılan ölçekler araştırmaların sonuç odaklı yapıldığını göstermiştir. İncelenen çalışmaların hiçbirinde süreç odaklı değerlendirmenin yapıldığına ilişkin bir bulgu elde edilememiştir. Yapılan çalışmada Montessori yaklaşımına ilişkin çalışmaların 2019 (n=7) ve 2016 (n=6) yıllarında diğer yıllara oranla daha fazla olduğu görülmüştür. Araştırma sonuçları araştırmaların daha çok görsel algı, bilişsel, dil ve sosyal gelişim üzerine yoğunlaştığını göstermektedir. Yapılacak olan çalışmalar çalışmalarda tüm gelişim alanları üzerine yapılabilir ve Türkiye'de uygulanan Montessori yöntemi genel bir bakışla değerlendirilebilir.

\section{Introduction}

Montessori method offers an alternative education opportunity to support the development of preschool children (Cossentino, 2006). At the beginning of the twentieth century, this method, which gained great acclaim in child education, became widespread in many countries (Miezitis, 1971). The Montessori method is widely applied in the world for more than a hundred years has started to be implemented in some of the university practice kindergartens and pre-schools affiliated with the Ministry of National Education in Turkey since the 2000s. It is also implemented as a pilot in institutions affiliated to the Ministry of National Education and as an alternative education model in private preschool education institutions.

The Montessori method can be applied with the same philosophy in many different geographies around the world. The reasons for the prevalence of the method can be cited as having a holistic perspective, child-centered learning, peer learning, prepared environment (that makes the child independent), and providing the child opportunities to learn by doing and experiencing. In addition, it can be said that the philosophy of the method is based on considering the child as an individual, focusing on the children's independency from adults, including cultural elements, and continuing in a dynamic process (Kayılı, 2015; Bozkurt, Kölemen, Abanoz \& Ulutaş, 2019). The basis of these features comes from Maria Montessori's constant observation of children, rearranging her educational methods and materials according to children's learning styles.

Montessori believes that children can learn best in a prepared environment with unique stimulating learning materials and specific routines with the guidance of the teacher (Montessori, 1966). Therefore, children are educated in a prepared environment. The program is carried out with teachers who interiorize child-centered learning and propose to work with materials in line with the development and interest of children. Teachers need to systematically observe children and record their practices to assess their learning process (Torrence \& Chattin-McNichols, 2005). The learning process includes support and practices for children's focus, intrinsic motivation, and peaceful coexistence. Observation records are also shared with children to draw attention to their development and motivate them to move on to the next stage (Lillard, 2005; Neubert, 1973; Oğuz \& Köksal, 2006). Moreover, unlike the continuous linear climbing in traditional education, the Montessori method varies according to each stage of the child's development and an individual education program is prepared for each child in the classroom (Lillard, 2005; Lillard, 2019; Money, 2000).

The materials in the Montessori classroom enable the child to learn by using their senses and to develop their self-esteem while reaching knowledge and skills step by step as the understanding that "children learn better when they do" prevails according to this method (Taner Derman, Sadioğlu, Bağçeli Kahraman \& Onur Sezer, 2010). Since there is only one of each material in the classroom setting, it contributes to the acquisition of certain values such as waiting for other's turn, respecting each other, patience, and tolerance (Lillard, 2005; Money, 2000; Montessori, 1966).

The Montessori method contributes to children's positive attitude towards school, self-discipline, self-motivation, being able to act independently, enjoying working and repetition, developing selfconfidence, providing permanent curiosity, and developing a sense of order (Yiğit, 2008). When the studies are examined, there are many studies in Turkey (Aral, Yıldız Bıçakçı, Yurteri Tiryaki, Çetin 
Kıran, Macun, Argın \& Ulutaş - Çukurova Üniversitesi Eğitim Fakültesi Dergisi, 50(2), 2021, 1154-1183

Sultanoğlu \& Şahin, 2015; Aydoğan, 2016; Buldur, 2019; Dereli, 2017; Güven, Gültekin \& Dedeoğlu, 2020; Kayılı, 2016a; Kayılı, 2016b; Kayılı \& Arı, 2011; Kayılı, Koçyiğit \& Erbay, 2009; Noyat, İnam Karahan \& Alakuş, 2019; Temel, Kaynak, Paslı, Demir \& Çemrek, 2016; Toran \& Temel, 2014; Yıldırım, Akman \& Alabay, 2012; Yıldız \& Çağdaş, 2019; Yıldızbaş \& Aslıyüksek, 2016; Yücesan \& Özyürek, 2017; Yüksek Usta \& Tezel Şahin, 2019) and abroad (Cossentino, 2006; Culclasure, Daoust, Cote \& Zoll, 2019; Kusumawardani, Nani \& Sulistiani, 2020; Lillard, 2012; Lillard, 2019; Lillard, Heise, , Richey, vd., 2017) where it is stated that the development of the child is supported with Montessori method. Most of the studies were quasi-experimental and survey research, working with children, teachers, and parents. Examining all the studies on the Montessori method, comparing them in terms of purpose, tools and findings, and synthesizing their results will provide detailed guidance for researchers. When these studies are discussed together, it will be possible to have a holistic view on the effect of the program and the factors affecting the education process. It will allow researchers to evaluate critical points in decision-making while planning a study on the Montessori method and will help them save time. Therefore, the main purpose of the research is to examine the articles about Montessori method in Turkey by systematic review. The following points were considered in the systematic review;

- Clearly stating the aims and objectives of the research,

- Defining the conceptual framework of the research adequately and clearly,

- The design of the research is suitable for the research questions,

- Clearly defining the content of the research,

- Defining adequately and clearly the sampling strategy,

- Defining adequately and clearly the sampling strategy,

- Stating adequately and clearly the analysis of the data,

- Supporting the findings with data,

- The suggestions are based on the findings,

- The methodological suitability of the articles,

Thus, it is aimed to examine the studies on the Montessori method in Turkey in depth in the literature.

\section{Method}

The main purpose of this research is to examine the articles about the Montessori method in Turkey with a systematic review method. Systematic review is the art and science of identifying, selecting and synthesizing primary research studies to provide a comprehensive and reliable framework for the subject under study. In systematic review research, findings are synthesized and interpreted in a balanced and neutral way (Crompton, Burke, \& Gregory, 2017). Findings are questioned according to clear contexts and research objectives, and the research is grounded on studies with a clear and rigorous design. Therefore, a comprehensive evidence-based review process is conducted by distinguishing between "evidence" and "experience" (Bettany-Saltikov, 2012).

\section{Data Collection}

In systematic review studies, various steps are followed from determining the purpose to putting down the study. First of all, it is ensured that the purpose is clearly defined, the studies included in the research are selected according to predetermined criteria, the basic characteristics of the selected studies are determined, and inferences are made in line with these data (Millar, 2004; Alkan, 2017). The steps followed in the systematic review can be listed as follows (Carol, Jill, \& Kate, 2017): 
Kıran, Macun, Argın \& Ulutaş - Çukurova Üniversitesi Eğitim Fakültesi Dergisi, 50(2), 2021, 1154-1183

1. Determining the research question: The research question, research process and timing are determined.

2. Protocol (planning the research design, conceptual basis, criteria, etc.): Evaluation tools, inclusion and exclusion criteria are identified.

3. Obtaining information and selection of studies (reviewing electronic resources, etc.): Sources are reviewed according to selection criteria, studies to be included in the research are recorded, reading and examinations are made.

4. Coding (defining and classifying studies): Studies are coded according to the developed checklist, and coding is done by more than one researcher. The generated codes are compared.

5. Quality assessment (revision of studies to be included in the study): The strengths and weaknesses of the studies are compared in terms of purpose, method, findings and discussion, and the reasons for inclusion and exclusion are explained.

6. Synthesis (integrating the results of studies): Studies are integrated by bringing them together in terms of purpose, method and findings.

7. Reporting writing and publishing: The study is put down on paper in accordance with the format to be published and published to be shared with other researchers.

In the preparation of this study, preferred reporting items for systematic reviews and meta-analyses statement-PRISMA was used (The PRISMA Statement, 2020).

\section{Sampling}

While reviewing the database in the research, reviews were made without any year restrictions and all studies related to Montessori were reached during March and April 2020. Some criteria were determined in the determination of the studies to be included in the research. It has been decided to include English and Turkish studies conducted in Turkey in the research, not to evaluate studies conducted outside of Turkey even if the language is Turkish, to examine only journal articles within the scope of the research, and to exclude works such as papers, dissertations, book chapters, etc. from the research.

To reach the articles in the research, Dergipark and TR Dizin databases were reviewed firstly. "Preschool and Montessori", "Early childhood and Montessori" were searched to define the common literature among the keywords. As a result of the keyword search, a total of 165 results were found, 108 of them obtained from "Preschool and Montessori" search and 57 of them obtained from "Early Childhood and Montessori" search, using Dergipark database between 10-20 April. A total of 18 results were reached using TR Dizin database, 14 of them were "Preschool and Montessori" search and four of them in the "Early childhood and Montessori" search. In addition, Google Scholar search was also done for the journal articles that could not be reached from these databases. Advanced search section was used in Google Schooler. "Montessori" was written in the part containing the exact word group, and "Preschool/Early childhood" was written in the part containing all the words. Google scholar provided a total of 1900 results, 1200 results of them were in the "Preschool and Montessori" search, 700 results of them were in the "Early childhood and Montessori" search. The titles of the articles accessed from the databases were reviewed and 81 articles were determined to be examined. Among the 81 articles, it was determined that some articles had both English and Turkish titles and that these duplicate articles were included twice, and the number was reduced to 75 .

The selection of articles took place in two steps: In the first step, the titles and abstracts of the studies obtained as a result of the search were reviewed according to their relevance. In the second step, it was determined whether the studies met the inclusion criteria by conducting full-text analysis. Inconsistencies between evaluators were resolved through discussion or consultation with the research methodologist who made the final decision. 
Kıran, Macun, Argın \& Ulutaş - Çukurova Üniversitesi Eğitim Fakültesi Dergisi, 50(2), 2021, 1154-1183

A thesis and a conference paper were excluded from the research by examining the summaries of 75 studies. 44 articles were extracted from 73 articles, including 17 review articles, an article covering one primary education period, 20 non-field articles, examples from four different countries, and an inaccessible article. The remaining 29 articles were included in the study to be analyzed separately in the weight of evidence table by each researcher. Seven articles were examined by the researchers in the weight of evidence table and were eliminated because their mean scores were low, and the remaining 22 articles were included in the study. The selection criteria of the articles included in the study are given in Table 1.

Table 1

Selection Criteria

\begin{tabular}{ll}
\hline Topic & Research on the Montessori method in early childhood \\
\hline Method & Quantitative, qualitative, and mixed methods studies \\
\hline Study group & $\begin{array}{l}\text { Preschool children, families of preschool children, preschool teachers, } \\
\text { preschool preservice teacher }\end{array}$ \\
\hline Language & Articles published in English and Turkish limited to studies done in Turkey \\
\hline Publication date & Articles published before 20 April 2020 \\
\hline
\end{tabular}

It is seen in Table 1 that the criteria of the topic, method, study group, language characteristics and publication date of the studies to be included in the systematic review are used.

\section{Data Analysis}

In the study, 29 articles were examined in depth and a Weight of Evidence/WoE table was developed for each article. The studies were examined in three sub-dimensions and a total WoE score was obtained by scoring 0-none, 1-somewhat, 2-mostly, 3-completely. The overall quality of the study was evaluated in WoE $A$, the methodological suitability and selected research designs in WoE $B$, and the scores obtained from the relevance/adequacy of the findings and the ethics of the research in WoE C. WoE D presents the average weight of evidence.

Under the WoE A heading;

- The aims and objectives of the research are clearly stated.

- The conceptual framework of the study is adequately and clearly defined.

- The design of the research is suitable for the research questions,

- The content of the study is clearly defined.

- The sampling strategy is adequately and clearly defined.

- Data collection is adequately and clearly defined.

- The analysis of the data is adequately and clearly stated.

- Findings are supported by data.

- Suggestions are based on findings.

Under the WoE B heading;

- The research is methodologically appropriate.

Under the WoE C heading;

- The research findings are suitable for the purpose of the research.

- The research findings are sufficient, items are included (Bereczkia \& Kárpáti, 2018). 
Kıran, Macun, Argın \& Ulutaş - Çukurova Üniversitesi Eğitim Fakültesi Dergisi, 50(2), 2021, 1154-1183

Seven studies with an average of 1.5 points or less in line with the weight of evidence table were eliminated. Eliminated studies were evaluated only based on the weight of evidence criteria. The PRISMA Flow Diagram as a result of all these stages is given in Figure 1.

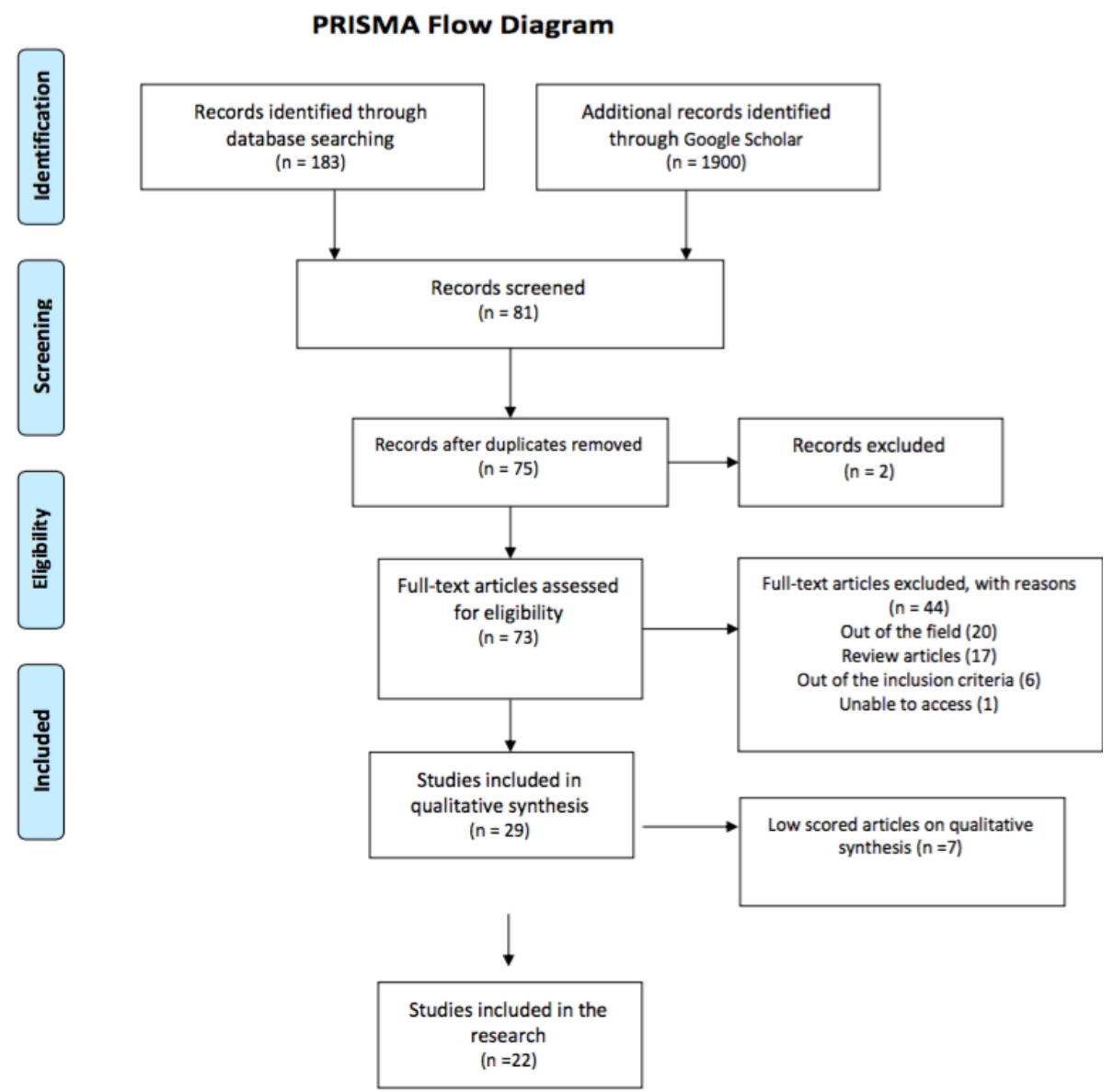

Figure 1. PRISMA Flow Diagram

Findings

As a result of the examinations in the systematic evaluation, a total of 22 studies were determined. In Table 2, the studies examined within the scope of the research and the purpose of their implementation are given in Table 2.

Table 2

Purpose of the Implementation of the Studies Examined within the Research

\begin{tabular}{|c|c|c|c|c|}
\hline & Author & Purpose & Measurement tool & Sample \\
\hline 1 & $\begin{array}{l}\text { Aral, Yıldız } \\
\text { Bıçakcı, Yurteri } \\
\text { Tiryaki, Çetin } \\
\text { Sultanoğlu \& } \\
\text { Şahin, } 2015\end{array}$ & $\begin{array}{l}\text { The effect of the Montessori } \\
\text { education on children's } \\
\text { developmental areas was examined. }\end{array}$ & $\begin{array}{l}\text { Developmental } \\
\text { Indicators for the } \\
\text { Assessment of Learning } \\
4 \text { (DIAL-4), } \\
\text { Developmental Profile } \\
3 \text { (DP-3) }\end{array}$ & 93 children \\
\hline 2 & Buldur, 2019 & $\begin{array}{l}\text { The scientific process skills of } 48-72 \\
\text { months old children who continue } \\
\text { their pre-school education and receive }\end{array}$ & $\begin{array}{l}\text { Basic Process Skills } \\
\text { Scale of towards Pre- } \\
\text { School Students }\end{array}$ & 60 children \\
\hline
\end{tabular}


Montessori education were examined.(BPSSPS)

\begin{tabular}{|c|c|c|c|c|}
\hline 3 & $\begin{array}{l}\text { Çakır, Altun } \\
\text { Yalçın \& Yalçın, } \\
2019\end{array}$ & $\begin{array}{l}\text { The effect of Montessori approach } \\
\text { based STEM activities on the } \\
\text { development of creativity skills of } \\
\text { preschool preservice teachers was } \\
\text { examined. }\end{array}$ & $\begin{array}{l}\text { "How Creative Are } \\
\text { You?" scale, Semi- } \\
\text { structured interview } \\
\text { forms }\end{array}$ & $\begin{array}{c}50 \\
\text { preservice } \\
\text { teachers }\end{array}$ \\
\hline 4 & Dereli, 2017 & $\begin{array}{l}\text { The effect of Montessori education } \\
\text { program on the psychosocial } \\
\text { development and social problem } \\
\text { solving skills of } 4-5 \text { year old children } \\
\text { attending pre-school education was } \\
\text { examined. }\end{array}$ & $\begin{array}{l}\text { Pre-school } \\
\text { Psychological } \\
\text { Observation Forms for } \\
\text { Children, Wally Child } \\
\text { Social Problem-Solving } \\
\text { Detective Game Test } \\
\end{array}$ & 160 children \\
\hline 5 & Kayılı \& Arı, 2016 & $\begin{array}{l}\text { It is aimed to examine the effect of } \\
\text { Montessori method on children's } \\
\text { ability to understand their emotions } \\
\text { and solve social problems. }\end{array}$ & $\begin{array}{l}\text { Wally Feelings Test and } \\
\text { Wally Social Problem } \\
\text { Solving Test }\end{array}$ & 53 children \\
\hline 6 & $\begin{array}{l}\text { Yücesan \& } \\
\text { Özyürek, } 2017\end{array}$ & $\begin{array}{l}\text { Problem behaviors of children who } \\
\text { received and did not receive } \\
\text { Montessori education in the preschool } \\
\text { period were examined. }\end{array}$ & $\begin{array}{l}\text { Preschool and } \\
\text { Kindergarten Behaviors } \\
\text { IScale (PKBS-2) }\end{array}$ & 60 children \\
\hline 7 & $\begin{array}{l}\text { Güven, Gültekin } \\
\& \text { Dedeoğlu, } \\
2020\end{array}$ & $\begin{array}{l}\text { It was investigated whether there is a } \\
\text { difference in sudoku solving skills } \\
\text { between the children who were } \\
\text { educated according to the Ministry of } \\
\text { National Education preschool } \\
\text { education curriculum and the } \\
\text { Montessori education. }\end{array}$ & $\begin{array}{l}\text { Sudoku Skills } \\
\text { Measurement Tool }\end{array}$ & 118 children \\
\hline 8 & Kayılı \& Arı, 2011 & $\begin{array}{l}\text { The effect of Montessori method on } \\
\text { preschool children's school readiness } \\
\text { was examined. }\end{array}$ & $\begin{array}{l}\text { Metropolitan Readiness } \\
\text { Test, PKBS Preschool } \\
\text { and Kindergarten } \\
\text { Behavior Scale, FTF-K } \\
\text { Attention Gathering } \\
\text { Skills Test }\end{array}$ & 50 children \\
\hline 9 & $\begin{array}{l}\text { Toran \& Temel, } \\
2014\end{array}$ & $\begin{array}{l}\text { The effect of the Montessori Method } \\
\text { on the concept acquisition of children } \\
\text { aged 4-6 was examined. }\end{array}$ & $\begin{array}{l}\text { Bracken Basic Concept } \\
\text { Scale-Revised Form }\end{array}$ & 48 children \\
\hline 10 & Kayılı, 2016a & $\begin{array}{l}\text { It is aimed to examine the effect of } \\
\text { Montessori method on the cognitive } \\
\text { tempo of } 4-5 \text { year old children. }\end{array}$ & $\begin{array}{l}\text { Kansas Reflection- } \\
\text { Impulsivity Scale for } \\
\text { Preschool - Form A }\end{array}$ & 60 children \\
\hline 11 & Aydoğan, 2016 & $\begin{array}{l}\text { Language development of preschool } \\
\text { children receiving Montessori } \\
\text { education was examined. }\end{array}$ & $\begin{array}{l}\text { Descoeudres Language } \\
\text { Test, Dictionary and } \\
\text { Language Test, Peabody } \\
\text { Picture-Vocabulary Test }\end{array}$ & 35 children \\
\hline 12 & $\begin{array}{l}\text { Kayılı, Koçyiğit \& } \\
\text { Erbay, } 2009\end{array}$ & $\begin{array}{l}\text { The effect of the Montessori method } \\
\text { on the receptive language skills of } \\
\text { five-six years old children was } \\
\text { investigated. }\end{array}$ & $\begin{array}{l}\text { Peabody Picture- } \\
\text { Vocabulary Test }\end{array}$ & 40 children \\
\hline
\end{tabular}


Kıran, Macun, Argın \& Ulutaş - Çukurova Üniversitesi Eğitim Fakültesi Dergisi, 50(2), 2021, 1154-1183

\begin{tabular}{|c|c|c|c|c|}
\hline 13 & $\begin{array}{l}\text { Noyat, İnam } \\
\text { Karahan \& } \\
\text { Alakuş, } 2019\end{array}$ & $\begin{array}{l}\text { The effect of Montessori method on } \\
\text { the creativity development of } \\
\text { preschool children was examined. }\end{array}$ & Observation form & 80 children \\
\hline 14 & $\begin{array}{l}\text { Temel, Kaynak, } \\
\text { Paslı, Demir \& } \\
\text { Çemrek, } 2016\end{array}$ & $\begin{array}{l}\text { The relationship between visual } \\
\text { perception and drawing skills of } \\
\text { children receiving Montessori } \\
\text { education was examined. }\end{array}$ & $\begin{array}{l}\text { Bender Gestalt Visual } \\
\text { motor Perception Test, } \\
\text { Goodenough-Harris } \\
\text { Draw-a- Person Test }\end{array}$ & 83 children \\
\hline 15 & $\begin{array}{l}\text { Yıldırım, Akman } \\
\text { \& Alabay, } 2012\end{array}$ & $\begin{array}{l}\text { The effect of Montessori and mandala } \\
\text { education on visual perception } \\
\text { behaviors of preschool children was } \\
\text { investigated. }\end{array}$ & $\begin{array}{l}\text { Frostig Visual } \\
\text { Perception Test }\end{array}$ & 36 children \\
\hline 16 & $\begin{array}{l}\text { Yıldız \& Çağdaş, } \\
2019\end{array}$ & $\begin{array}{l}\text { Mathematics and daily life skills of 4-5 } \\
\text { years old children whose mothers' } \\
\text { received Montessori Mother Support } \\
\text { Education were examined. }\end{array}$ & $\begin{array}{l}\text { Mathematics (MATH) } \\
\text { and Daily Living Skills } \\
\text { (DLS) - of the Basic } \\
\text { School Skills Inventory } 3 \\
\text { (BSSI) }\end{array}$ & 19 children \\
\hline 17 & $\begin{array}{l}\text { Yıldızbaş \& } \\
\text { Aslıyüksek, } 2016\end{array}$ & $\begin{array}{l}\text { The effectiveness of the Montessori } \\
\text { education program in acquiring motor } \\
\text { skills, visual perception, memory, } \\
\text { hand-eye coordination and fine motor } \\
\text { skills of 4-5 year old children was } \\
\text { examined. }\end{array}$ & $\begin{array}{l}\text { Gesell Development } \\
\text { Test, Denver II } \\
\text { Developmental } \\
\text { Screening Test }\end{array}$ & 40 children \\
\hline 18 & $\begin{array}{l}\text { Yüksek Usta \& } \\
\text { Tezel Şahin, } \\
2019\end{array}$ & $\begin{array}{l}\text { It was carried out to determine the } \\
\text { awareness of children attending } \\
\text { Montessori kindergarten and children } \\
\text { attending public kindergarten about } \\
\text { the world and geographical concepts. }\end{array}$ & Child Interview Form & 32 children \\
\hline 19 & $\begin{array}{l}\text { Zembat, Günşen } \\
\text { \& Gök Çolak, } \\
2019\end{array}$ & $\begin{array}{l}\text { It is aimed to determine the views of } \\
\text { preschool teachers about the } \\
\text { philosophers who shaped preschool } \\
\text { education and the approaches they } \\
\text { represent. }\end{array}$ & $\begin{array}{l}\text { Two different semi- } \\
\text { structured interview } \\
\text { protocols were } \\
\text { developed by the } \\
\text { researcher. }\end{array}$ & $\begin{array}{l}20 \text { preschool } \\
\text { teachers }\end{array}$ \\
\hline 20 & $\begin{array}{l}\text { Atlı, Korkmaz, } \\
\text { Taştepe \&Köksal } \\
\text { Akyol, } 2016\end{array}$ & $\begin{array}{l}\text { It is aimed to determine the opinions } \\
\text { of preschool teachers who serve at } \\
\text { the schools applying the Montessori } \\
\text { approach. }\end{array}$ & $\begin{array}{l}\text { A semi-structured } \\
\text { interview form }\end{array}$ & $\begin{array}{l}9 \text { preschool } \\
\text { teachers }\end{array}$ \\
\hline 21 & Şahin Sak, 2014 & $\begin{array}{l}\text { The aim was to determine the views } \\
\text { of preschool preservice teachers } \\
\text { about Montessori and Reggio Emilia } \\
\text { approaches. }\end{array}$ & Reflection papers & $\begin{array}{c}30 \\
\text { preservice } \\
\text { teachers }\end{array}$ \\
\hline 22 & $\begin{array}{l}\text { Bozkurt, } \\
\text { Kölemen, } \\
\text { Abanoz \& } \\
\text { Ulutaş, } 2019\end{array}$ & $\begin{array}{l}\text { The study was carried out to } \\
\text { determine the Montessori education } \\
\text { perceptions of the parents' of children } \\
\text { receiving Montessori education. }\end{array}$ & $\begin{array}{l}\text { Form for Determining } \\
\text { Parents' Opinions on } \\
\text { Montessori Education }\end{array}$ & 25 parents \\
\hline
\end{tabular}

As seen in Table 2, when the purposes of the researches were examined in terms of parents, it was determined that the parents' perceptions of the Montessori method were examined (Bozkurt et al., 2019). In terms of children, it is seen that children's geographical concept awareness (Yüksek Usta \& Tezel Şahin, 2019), concept acquisitions (Toran \& Temel, 2014), visual perception skills (Temel et al., 2016; Yıldızbaş \& Aslıyüksek, 2016), drawing skills (Temel et al. , 2016), scientific process skills (Buldur, 2019), sudoku solving skills (Güven, et al., 2020), language development (Aydoğan, 2016), psycho-social 
Kıran, Macun, Argın \& Ulutaş - Çukurova Üniversitesi Eğitim Fakültesi Dergisi, 50(2), 2021, 1154-1183

development (Dereli, 2017), school readiness (Kayılı \& Arı, 2011), social problem solving skills (Dereli, 2017; Kayılı \& Arı, 2016), examination of children's problematic behaviors (Yücesan \& Özyürek, 2017), motor skills (Yıldızbaş \& Aslıyüksek, 2016), memory (Yıldızbaş \& Aslıyüksek, 2016), hand-eye coordination (Yıldızbaş \& Aslıyüksek, 2016), fine motor skills (Yıldızbaş \& Aslı Yüksek, 2016), receptive language skills (Kayılı et al., 2009), visual perception (Yıldırım, et al., 2012), creativity (Noyat, et al., 2019), cognitive tempo (Kayılı, 2016a), ability to understand emotions (Kayılı \& Arı, 2016) and the effect of Montessori support education given to mothers on children's mathematics and daily life skills (Yıldız \& Çağdaş, 2019) has been studied. In terms of preservice teachers, it is seen that the effect of the Montessori program on the creativity skills of the preservice teachers (Çakır, et al., 2019) and the opinions of the preservice teachers about the Montessori and Reggio Emilia approaches (Şahin Sak, 2014) are studied. In terms of teachers, studies were conducted on teachers views on philosophers who shape preschool education and their approaches (Zembat, et al., 2019) and teachers' views on Montessori approach (Atll, et al., 2016). The distribution of studies by sampling is given in Table 3.

Table 3

Distribution of Studies by Sampling

\begin{tabular}{llr}
\hline Sample & Articles & $f$ \\
\hline Children & Aral et al., 2015; Aydoğan, 2016; Buldur, 2019; Dereli, & 17 \\
& 2017; Güven et al., 2020; Kayılı \& Ari, 2011; Kayılı \& Ari, & \\
& 2016; Kayılı, 2016a; Kayılı et al., 2009; Noyat et al., 2019; \\
& Temel et al., 2016; Toran \& Temel, 2014; Yıldırım et al., & \\
& 2012; Yıldız \& Çağdaş, 2019; Yıldızbaş \& Aslıyüksek, 2016; \\
& Yücesan \& Özyürek, 2017; Usta \& Tezel Şahin, 2019 & 2 \\
\hline Preschool teachers & Atlı et al., 2016; Zembat et al., 2019 & 1 \\
\hline Parents & Bozkurt et al., 2019 & 2 \\
\hline Preservice teachers & Çakır et al., 2019; Şahin Sak, 2014 & 22 \\
\hline Total & & \\
\hline
\end{tabular}

According to Table 3, the sample groups of the studies consisted of parents in one article (4.55\%), children in 17 articles (77.27\%), teachers in two articles (9.09\%), and preservice teachers in two articles (9.09\%). The distribution of studies by research design is given in Table 4.

Table 4

Distribution of Studies by Research Design

\begin{tabular}{lllc}
\hline Research Method & Articles & $f$ \\
\hline $\begin{array}{l}\text { Quantitative } \\
\text { Euasi- } \\
\text { Experimental }\end{array}$ & Dereli, 2017; Yıldızbaş \& Aslıyüksek, 2016 & 2 \\
\hline & $\begin{array}{l}\text { Longitudinal } \\
\text { Survey }\end{array}$ & Buldur, 2019 & 1 \\
\hline & Survey & Temel et al., 2016 & 1 \\
\hline & Experimental & Aral et al., 2015; Aydoğan, 2016; Güven et al., 2020; Kayılı \& Ari, & 10 \\
\hline & & 2011; Kayılı \& Ari, 2016; Kayılı et al., 2009; Kayılı, 2016a; Toran & \\
\hline & \& Temel, 2014; Yıldırım et al., 2012; Yıldız \& Çağdaş, 2019 & 1 \\
\hline Qualitative & Phenomenology & Bozkurt et al., 2019; Zembat et al., 2019 & 5 \\
\hline & Unspecified & Atlı et al., 2016; Noyat et al., 2019; Şahin Sak, 2014; Usta \& & 5 \\
\hline $\begin{array}{l}\text { Mixed } \\
\text { method }\end{array}$ & Tezel Şahin, 2019 & 1 \\
\hline Total & Çakır et al., 2019 & 22 \\
\hline
\end{tabular}


Kıran, Macun, Argın \& Ulutaş - Çukurova Üniversitesi Eğitim Fakültesi Dergisi, 50(2), 2021, 1154-1183

As is shown in Table 4, 15 of the studies included in the systematic review were carried out with the quantitative method, six with qualitative method, and one with mixed method design. In Figure 2, the distribution of the studies included in the study according to research designs is presented.

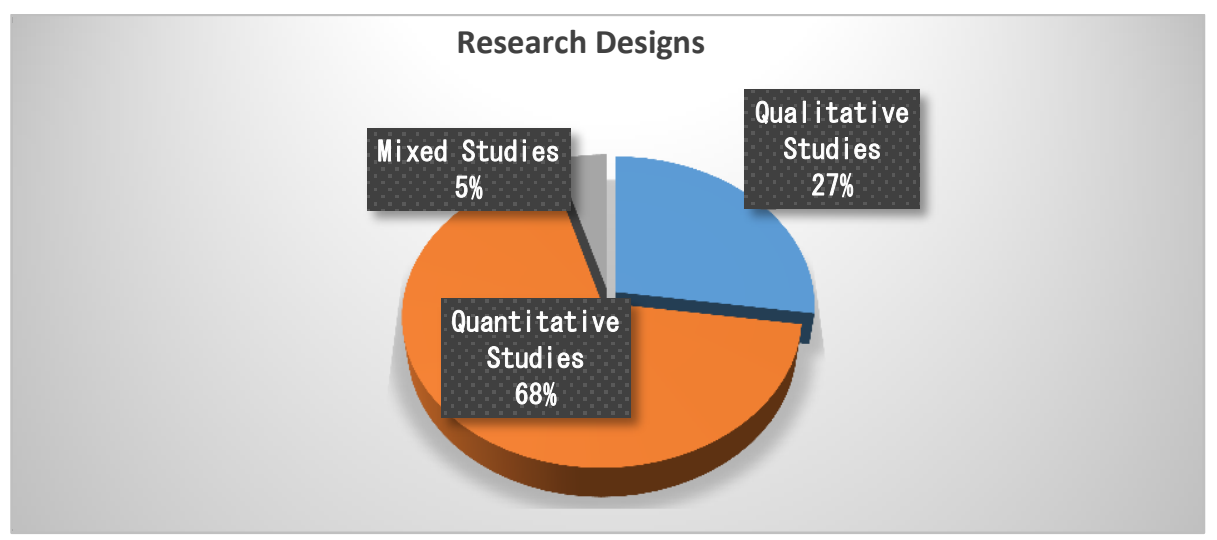

Figure 2. Distribution of Studies by Research Design

Table 5 shows the distribution of the studies included in the systematic review by year of publication.

Table 5

Distribution of Studies by Publication Year

\begin{tabular}{llc}
\hline Year & Articles & $f$ \\
\hline 2009 & Kayılı, Koçyiğit \& Erbay, 2009 & 1 \\
\hline 2011 & Kayılı \& Arı, 2011 & 1 \\
\hline 2012 & Yıldırım, Akman \& Alabay, 2012 & 1 \\
\hline 2014 & Şahin Sak, 2014; Toran \& Temel, 2014 & 2 \\
\hline 2015 & Aral, Yıldız Bıçakcı, Yurteri Tiryaki, Çetin Sultanoğlu \& Şahin, 2015 & 1 \\
\hline 2016 & Atlı, Korkmaz, Taştepe \& Köksal Akyol, 2016; Aydoğan, 2016; Kayılı, 2016a; Kayılı \& & 6 \\
& Arı, 2016; Temel, Kaynak, Paslı, Demir \& Çemrek, 2016; Yıldızbaş \& Aslıyüksek, & \\
\hline & 2016 & 2 \\
\hline 2017 & Dereli, 2017; Yücesan \& Özyürek, 2017 & 7 \\
\hline 2019 & Bozkurt, Kölemen, Abanoz \& Ulutaş, 2019; Buldur, 2019; Çakır, Altun Yalçın \& \\
& Yalçın, 2019; Noyat, İnam Karahan \& Alakuş, 2019; Yıldız \& Çağdaş, 2019; Yüksek & 1 \\
\hline Usta \& Tezel Şahin, 2019; Zembat, Günşen \& Gök Çolak, 2019 & 22 \\
\hline Total & Güven, Gültekin \& Dedeoğlu, 2020 & \\
\hline
\end{tabular}

According to Table 5, it is seen that the largest number of studies were published in 2019 with seven articles. Six articles published in 2016, two articles published in 2014 and 2017, and one article published in 2009, 2011, 2012, 2015, and 2020 were included in the study. Figure 3 shows the distribution of studies by year. 


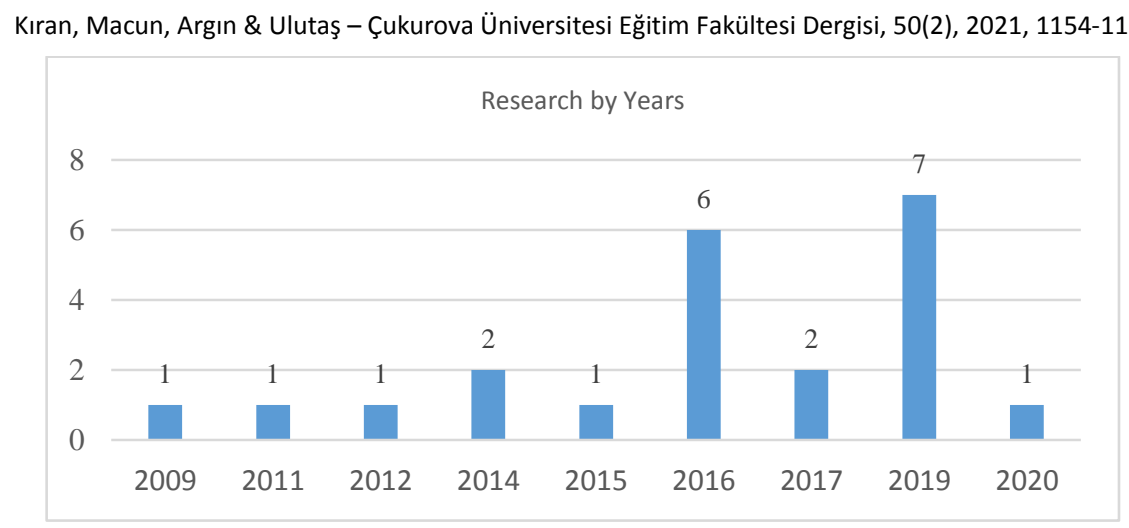

Figure 3. Distribution of Studies by Publication Year

Data collection tools used in the studies included are given in Table 6.

Table 6

Data Collection Tools Used in Studies and Studies Used

\begin{tabular}{|c|c|c|}
\hline Data collection tools & Articles & $f$ \\
\hline Interview & $\begin{array}{l}\text { Semi-Structured Interview (Bozkurt, Kölemen, Abanoz \& Ulutaş, } \\
\text { 2019; Çakır et al., 2019; Yüksek Usta \& Tezel Şahin, 2019; Zembat } \\
\text { et al., 2019; Atlı et al., 2016) }\end{array}$ & 5 \\
\hline Observation form & (Noyat et al., 2019) & 1 \\
\hline Reflection paper & (Şahin Sak, 2014) & 1 \\
\hline \multirow[t]{21}{*}{ Scale } & $\begin{array}{l}\text { Sudoku Skills Measurement Tool (Güven, Gültekin \& Dedeoğlu, } \\
\text { 2020) }\end{array}$ & 1 \\
\hline & Descoeudres Language Test (Aydoğan, 2016) & 1 \\
\hline & Bracken Basic Concept Scale-Revised Form (Toran \& Temel, 2014) & 1 \\
\hline & Dictionary and Language Test (Aydoğan, 2016) & 1 \\
\hline & $\begin{array}{l}\text { Denver II Developmental Screening Test (Yıldızbaş \& Aslıyüksek, } \\
\text { 2016) }\end{array}$ & 1 \\
\hline & $\begin{array}{l}\text { Peabody Picture Vocabulary Test (Aydoğan, 2016; Kayılı, Koçyiğit \& } \\
\text { Erbay, 2009) }\end{array}$ & 2 \\
\hline & Gesell Development Test (Yıldızbaş \& Aslıyüksek, 2016) & 1 \\
\hline & Metropolitan Readiness Test (Kayılı \& Arı, 2011) & 1 \\
\hline & $\begin{array}{l}\text { PKBS Preschool and Kindergarten Behavior Scale (Kayılı \& Arı, } \\
\text { 2011; Yücesan \& Özyürek, 2017) }\end{array}$ & 2 \\
\hline & FTF-K Attention Gathering Skills Test (Kayılı \& Arı, 2011) & 1 \\
\hline & Kansas Reflection-Impulsivity Scale for Preschoolers (Kayılı, 2016a) & 1 \\
\hline & Bender Gestalt Visual motor Perception Test (Temel et al., 2016) & 1 \\
\hline & Basic School Skills Inventory 3 (Yıldız \& Çağdaş, 2019) & 1 \\
\hline & Wally Feelings Test (Kayılı \& Arı, 2016) & 1 \\
\hline & Wally Social Problem Solving Test (Kayılı \& Arı, 2016; Dereli, 2017) & 2 \\
\hline & Goodenough-Harris Draw a Person Test(Temel et al., 2016) & 1 \\
\hline & $\begin{array}{l}\text { Basic Process Skills Scale of towards Pre-School Students (BPSSPS) } \\
\text { (Buldur, 2019) }\end{array}$ & 1 \\
\hline & $\begin{array}{l}\text { Pre-school Psychological Observation Forms for Children (Dereli, } \\
\text { 2017) }\end{array}$ & 1 \\
\hline & $\begin{array}{l}\text { Developmental Indicators for the Assessment of Learning } 4 \text { (DIAL- } \\
\text { 4) (Aral et al., 2015) }\end{array}$ & 1 \\
\hline & Developmental Profile 3 (DP3) (Aral et al., 2015) & 1 \\
\hline & Scale of How Creative Are You? (Çakır et al., 2019) & 1 \\
\hline
\end{tabular}


As stated in Table 6, semi-structured interview forms were used in five studies, and an observation form and reflection papers were used in one study. In quantitative and mixed studies, 22 different scales were used. It is noteworthy that all of the interviews were conducted through a semi-structured interview form. In addition, studies were generally carried out using a single measurement tool. In Table 7 , the topics investigated in the studies and their frequency values are given.

Table 7

The Topics in the Studies

\begin{tabular}{llc}
\hline The Topic & Articles & $f$ \\
\hline Views/Perceptions & Atlı et al., 2016; Bozkurt et al., 2019; Şahin Sak, 2014; Yıldırım et al., 2012; & 6 \\
& Yıldızbaş \& Aslıüksek, 2016 ; Zembat et al., 2019 & \\
\hline Skills & Buldur, 2019; Çakır et al., 2019; Dereli, 2017; Güven et al., 2020; Kayılı \& & 10 \\
& $\begin{array}{l}\text { Arı, 2016; Kayılı et al., 2009 ; Kayılı, 2016a; Temel et al., 2016; Yıldız \& } \\
\text { Çağdaş, 2019; Yıldızbaş \& Aslıüksek, 2016 }\end{array}$ & 3 \\
\hline Development & Aral et al., 2015; Aydoğan, 2016; Dereli, 2017 & 2 \\
\hline Concept & Toran \& Temel, 2014; Yüksek Usta \& Tezel Şahin, 2019 & 2 \\
awareness/acquisit & & 1 \\
\hline ion & & 1 \\
\hline School Readiness & Kayılı \& Arı, 2011; Toran \& Temel, 2014 & \\
\hline Behaviour & Yücesan \& Özyürek, 2017 & \\
\hline Creativity & Noyat et al., 2019 & \\
\hline
\end{tabular}

According to Table 7, views and perceptions were examined in six studies, skills in 10, development in three, concept awareness/acquisition in two, school readiness one, and problem behavior and creativity in one study. When the findings of the studies were examined, it was determined that Montessori method is effective in children's visual perception skills (Yıldırım et al., 2012; Yıldızbaş \& Aslıyüksek, 2016), concept acquisitions (Toran \& Temel, 2014), ability to understand emotions and social problem solving (Kayılı \& Arı, 2016), cognitive tempo (Kayılı, 2016a), scientific thinking skills (Buldur, mothers received Montessori education (Yıldız \& Çağdaş, 2019), understanding of geographical concepts (Yüksek Usta \& Tezel Şahin, 2019), language skills (Aydoğan, 2016; Kayılı et al., 2009), school readiness (Kayılı \& Arı, 2011; Toran \& Temel, 2014), development (Aral et al., 2015), motor skills (Yıldızbaş \& Aslıyüksek, 2016), psycho-social development and social problem-solving skills (Dereli, 2017), sudoku solving skills (Güven et al., 2020). As the duration of children's Montessori education increases, their visual perception skills increase (Temel et al., 2016), Findings pointed out that the studies focused on mostly visual perception skills, cognitive skills (concept acquisition, mathematics skills, school readiness, etc.) and social development.

In the study conducted with preschool teachers, it was determined that teachers knew the Montessori Approach the most (Zembat et al., 2019). Montessori teachers stated that they internalized the approach and that when the approach is applied correctly, the criticisms are unfounded (Atlı et al., 2016). In the research conducted with preservice teachers, the preservice teachers stated that the prepared classroom environment, use of real materials, and philosophy of the method help the children gain self-control skills; however, half of the preservice teachers stated that they thought the approach was not applicable in Turkey (Şahin Sak, 2014). In addition, it was determined that Montessori-based STEM activities positively affected the creativity skills of preservice teachers (Çakır et al., 2019).

Finally, parents stated that they preferred the Montessori approach because they saw it as a contemporary approach, they were satisfied with the content of the education, and they thought that education prepared their children for life (Bozkurt et al., 2019). 


\section{Discussion and Recommendations}

Within the scope of the study, it was aimed to examine the studies conducted in Turkey on the Montessori method by systematic review. In the study, 22 research articles were examined. Among the reviewed studies, 15 studies using quantitative research methods (two quasi-experimental, two longitudinal, one correlational survey, one survey, and 10 experimental). Six articles using qualitative research methods (two phenomenology and four with not specified designs) and one article using mixed methods research. The samples of the studies were grouped under four headings as child, teacher, preservice teachers, and parents. Since the target audience of the program is children, it can be said that the studies focused mostly on children. However, the perspective of the parents and the teacher in preschool education will also contribute to the problems encountered in the implementation of the program. In future studies, parents and teacher participation can be considered, and the child, teacher, and parent dimensions can be evaluated together.

Among the studies, the ones with the highest sample size are Dereli (2017) with 160 children, and Güven, Gültekin \& Dedeoğlu (2020) with 118 children. On the other hand, the sample size of other studies varies between 9 and 93. The low number of schools that apply the Montessori method in accordance with its philosophy in Turkey limits the number of participants to be included in the study group. Therefore, the limited sample sizes should be considered in the studies to be carried out, and it should be considered how much the schools to be included in the research adopt the principles of the Montessori program.

It was observed that a valid and reliable scale or test was used in 16 of the 22 articles examined in the study, interview forms were used in five studies, and an observation report was used in one study. When these studies were examined in terms of research method, it was seen that semi-structured interview forms were used in five of the six qualitative studies, and an observation form and a reflection paper were used in one study. It was noted that all the studies using the quantitative research method used scales with high validity and reliability, while a semi-structured observation form was used in a mixed method study. Conducting mixed method studies to reveal the outputs or relationships related to the program will provide more detailed findings.

The studies can be interpreted as result-oriented studies the fact that most of the studies conducted are quantitative studies and the scales used. In any of the studies examined, no finding was found that process-oriented evaluation was carried out. However, the Montessori education philosophy supports a process-oriented education rather than the result oriented (Lillard, 2019; Temel \& Toran, 2019) as the Montessori method aims at the continuity of the learning motivation of the child (Kuşçu, Bozdaş \& Yıldırım Doğru, 2014). Therefore, in Montessori studies, a process-oriented evaluation should be put forward. For example, many elements such as what the teacher does during the observation process, the content of the records, the interaction of children in peer learning will be revealed more clearly in the process evaluation, and the features of the Montessori method will be more observable.

In the study, it was seen that studies on the Montessori approach were more common in $2019(n=7)$ and $2016(n=6)$ compared to other years. In a compilation study conducted in Turkey, Kayılı (2016b) stated that there were more studies in $2006(n=6), 2011(n=5)$, and $2012(n=5)$. When the foreign literature studies are examined, Culclasure (2019) stated that the studies are more common in 2017 $(n=6)$ in their study. Therefore, it has been determined that there has been an increase in studies on Montessori education in recent years. This may be due to the interest in child-centered programs as well as the widespread use of the method. Danişman (2012) stated that schools using child-centered education approach have become popular and Montessori approach is the most preferred among these approaches. In this context, it will be easier to form a study group in future studies on Montessori, and it will also provide data to researchers in terms of revealing the differences in practice between schools.

In the articles examined in the study, in two of the studies whose sample was children, children who received Montessori education and children who received education in public schools, and in two of them, children who received and did not receive Montessori education were compared in terms of 
Kıran, Macun, Argın \& Ulutaş - Çukurova Üniversitesi Eğitim Fakültesi Dergisi, 50(2), 2021, 1154-1183

various skills. In 13 studies with a sample of children, the effect of Montessori education on a certain developmental area or level of children was examined. However, Montessori education aims to support the holistic development of children. Visual perception and attention were examined in four studies, cognitive development in three studies, psycho-social development in two studies, concept acquisition levels in two studies, and school readiness, motor development, all development areas, creativity, and self-care skills in one study, respectively. The results of the research show that the studies mostly focus on visual perception, cognitive, language, and social development. Instead of focusing on specific development areas, it will be possible to compare all development areas and evaluate all aspects of Montessori education in Turkey.

As a result, the research findings drew attention to most studies focused on the output of the Montessori method on children and their development, the necessity of studies examining the process, the rarity of qualitative or mixed methods studies, and the limitation of reaching the study group. In the study, it was tried to present the studies conducted in Turkey objectively with a systematic review, to present the evidence about the Montessori method to the researchers, and to present recommendations for future studies. In future studies, the systematic analysis can be updated and different study groups can be reached by changing inclusion criteria. In addition, foreign literature can be considered, so that a global interpretation of the Montessori method can be obtained.

All rules included in the "Directive for Scientific Research and Publication Ethics in Higher Education Institutions" have been adhered to, and none of the "Actions Contrary to Scientific Research and Publication Ethics" included in the second section of the Directive have been implemented. 


\section{Türkçe Sürümü}

\section{Giriş}

Montessori yöntemi okul öncesi dönemdeki çocukların gelişimlerini desteklemede alternatif bir eğitim imkânı sunmaktadır (Cossentino, 2006). Yirminci yüzyılın başlarında çocuk eğitimi konusunda büyük beğeni kazanan bu yaklaşım, ABD ile beraber farklı ülkelerde de yaygınlaşmıştır (Miezitis, 1971). 100 yılı aşkın bir süredir dünya üzerinde yaygın bir şekilde uygulanan eğitim modeli tüm dünyada olduğu şekliyle 2000'li yıllardan itibaren Türkiye'de de üniversite uygulama anaokulları ve Milli Eğitim Bakanlığına bağlı okul öncesi eğitim kurumlarının bazılarında uygulanmaya başlanmıştır. Yaklaşım, MEB'e bağı kurumlarda pilot olarak ve özel okul öncesi eğitim kurumlarında alternatif eğitim modeli olarak uygulanmaktadır.

Montessori yöntemi dünya üzerinde birçok farklı coğrafyada aynı felsefeyle uygulanabilmektedir. Yaklaşımın yaygınlığının nedenleri olarak çocuk merkezli öğrenmenin olması, çocuğu kendi çevresinde bağımsızlaştıran hazırlanmış çevreye sahip olması, çocuğa yaparak ve yaşayarak öğrenme fırsatları ve bireysel eğitim imkânı sunması, akran öğrenmesini içermesi ve holistik bakış açısına sahip olması gibi birçok özellik söylenebilir. Bunlara ek olarak yaklaşım felsefesinin temelinde çocuğun birey olarak görülmesi, yetişkinden bağımsızlaştırılmasına odaklanması, kültürel öğelere yer vermesi ve dinamik bir süreç içerisinde halen devam etmesi söylenebilir (Kayılı, 2015; Bozkurt, Kölemen, Abanoz \& Ulutaş, 2019). Bu özelliklerin de temelinde Maria Montessori'nin çocukları sürekli gözlemlemesi, eğitim yöntemini ve materyallerini onların öğrenme tepkilerine göre yeniden düzenlemesi yatmaktadır.

Montessori çocukların en iyi öğrenmeyi, öğretmen rehberliğinde uyarıcı öğrenme materyallerini ve deneyimlerini düzenli bir format içinde çocuğa sunan, kendine has materyalleri bulunan, tasarlanmış bir çevrede sağlayabileceğine inanmaktadır (Montessori, 1966). Bu nedenle çocuklar, özel hazırlanmış bir çevrede eğitim görmektedir. Buna ek olarak çocukların gelişimi ve ilgisi doğrultusunda materyallerle çalışma teklifinde bulunan, uygulamalarını gözlemleyerek, kayıt altına alan çocuk merkezli bir öğretmen ile program yürütülmektedir (Torrence \& Chattin-McNichols, 2005). Öğrenme süreci çocukların odaklanmasına, içsel motivasyonuna ve birlikte barış içinde yaşamaya yönelik desteği ve uygulamaları içerir. Gözlem kayıtları çocuklar ile de paylaşılarak gelişimlerine dikkat çekilir ve bir sonraki aşamaya geçmeleri için motive edilir (Lillard, 2005; Neubert, 1973; Oğuz \& Köksal, 2006). Bu duruma ek olarak geleneksel eğitimdeki sürekli doğrusal tırmanışın aksine, Montessori yöntemi çocuğun gelişimindeki her aşamaya göre değişiklik gösterir ve sınıfta bulunan her bir çocuk için bireysel eğitim programı hazırlanır (Lillard, 2005; Lillard, 2019; Money, 2000).

Montessori sınıf ortamında bulunan materyaller çocuğun duyularını kullanarak öğrenmesini, aşama aşama bilgi ve beceriye ulaşırken benlik saygısını da geliştirmesini sağlar. Çünkü bu yaklaşıma göre "çocuklar bir şeyleri yaptıkları zaman daha iyi öğrenirler anlayışı" hâkimdir (Taner Derman, Sadioğlu, Bağçeli Kahraman \& Onur Sezer, 2010). Sınıf ortamında her materyalden sadece birer tane bulunması nedeniyle sırasını bekleme, birbirine saygı duyma, sabretme ve hoşgörü gibi bazı değerlerin çocuklara kazandırılmasında katkıda bulunur (Lillard, 2005; Money, 2000; Montessori, 1966).

Montessori yönteminin çocuklara; okula karşı olumlu tutum, öz disiplin, öz motivasyon kazanımı, bağımsız olarak hareket edebilme, tekrardan ve çalışmaktan zevk alma, kendine güven geliştirebilme, kalıcı merakın sağlanması ve düzen duygusunun gelişmesi noktasında katkıları bulunmaktadır (Yiğit, 2008). Yapılan çalışmalar incelendiğinde Montessori ile çocuğun gelişiminin desteklendiğinin belirtildiği yurt içinde (Aral, Yıldız Bıçakçı, Yurteri Tiryaki, Çetin Sultanoğlu \& Şahin, 2015; Aydoğan, 2016; Buldur, 2019; Dereli, 2017; Güven, Gültekin \& Dedeoğlu, 2020; Kayılı, 2016a; Kayılı, 2016b; Kayılı \& Arı, 2011; Kayılı, Koçyiğit \& Erbay, 2009; Noyat, İnam Karahan \& Alakuş, 2019; Temel, Kaynak, Paslı, Demir \& Çemrek, 2016; Toran \& Temel, 2014; Yıldırım, Akman \& Alabay, 2012; Yıldız \& Çağdaş, 2019; Yıldızbaş \& Aslıyüksek, 2016; Yücesan \& Özyürek, 2017; Yüksek Usta \& Tezel Şahin, 2019) ve yurt dışında 
Kıran, Macun, Argın \& Ulutaş - Çukurova Üniversitesi Eğitim Fakültesi Dergisi, 50(2), 2021, 1154-1183

(Cossentino, 2006; Culclasure, Daoust, Cote \& Zoll, 2019; Kusumawardani, Nani \& Sulistiani, 2020; Lillard, 2012; Lillard, 2019; Lillard, Heise, , Richey, vd., 2017) birçok çalışma bulunmaktadır. Çalışmaların birçoğu yarı deneysel ve tarama türünde yapılmış, çocuk, öğretmen ve ebeveynler ile çalışılmıştır. Montessori yöntemine ilişkin uzun süredir birbirinden bağımsız olarak yapılan bu çalışmaların bir araya getirilerek amaç, araç, bulgu bakımından karşılaştırılması, sonuçlarının sentezlenmesi araştırmacılara detaylı bir rehberlik sağlayacaktır. Bu araştırmalar birlikte ele alındığında programın etkisine, eğitim sürecini etkileyen faktörlere ilişkin bütünsel bir bakış da mümkün olabilecektir. Araştırmacılara Montessori yöntemi ile ilgili çalışma planlarken karar vermede kritik noktaların değerlendirilmesine imkan verecek, zaman bakımından tasarruf sağlayacaktır. Dolayısıyla araştırmanın temel amacı Türkiye'de Montessori yöntemi ile ilgili hazırlanmış makalelerin sistematik derleme yöntemi ile incelenmesidir. Böylece alanyazında Türkiye'de Montessori yönteminin durumunun derinlemesine incelenmiş olması hedeflenmektedir. Yapılan bu çalışmada da yurt içinde Montessori yöntemi hakkında yayımlanan tüm makalelerin;

- Araştırmanın amaçları ve hedeflerini açıkça belirtme,

- Araştırmanın kavramsal çerçevesini yeterli ve açık bir şekilde tanımlama,

- Araştırmanın deseninin araştırma sorularına uygun olması,

- Araştırmanın içeriğinin açıkça tanımlanması,

- Örnekleme stratejisinin yeterli ve açık bir şekilde tanımlanması,

- Veri toplamasının yeterli ve açık bir şekilde tanımlanması,

- Verilerin analizinin yeterli ve açık bir şekilde belirtilmiş olması,

- Bulgularının verilerle desteklenmesi,

- Idddiaların bulgulara dayanması,

- Makalelerin yöntemsel uygunlukları,

- Bulgularının uygunluğu/yeterliliği göz önünde bulundurularak sistematik derleme yapılmıştır.

\section{Yöntem}

Bu araştırmanın temel amacı Türkiye'de Montessori yöntemi ile ilgili hazırlanmış makalelerin sistematik derleme yöntemi ile incelenmesidir. Sistematik derleme incelenen konunun kapsamlı ve güvenilir çerçevesini ortaya koymak için birincil araştırma çalışmalarını belirleme, seçme ve sentezleme sanatı ve bilimidir. Sistematik araştırmada bulgular dengeli ve tarafsı bir şekilde sentezlenir ve yorumlanır (Crompton, Burke \& Gregory, 2017). Bulgular net bağlamlara ve araştırma amaçlarına göre sorgulanır, açık ve titiz bir tasarıma sahip çalışmalar temel alınır. Bu nedenle, "kanıt" ve "deneyim" arasında ayrım yapılarak kanıta dayalı kapsamlı bir inceleme süreci yürütülür (Bettany-Saltikov, 2012).

\section{Verilerin Toplanması}

Sistematik derleme çalışmalarında amacın belirlenmesinden çalışmanın yazılmasına kadar çeşitli basamaklar takip edilmektedir. Öncelikle amacın açık bir şekilde belirlenmesi, araştırmaya alınan çalışmaların daha önceden belirlenmiş ölçütlere göre seçilmesi, seçilen çalışmaların temel özelliklerinin belirlenmesi ve elde edilen bu veriler doğrultusunda çıkarıma gidilmesi sağlanmaktadır (Millar, 2004; Alkan, 2017). Sistematik derlemede takip edilen basamaklar şöyle sıralanabilir (Carol, Jill \& Kate, 2017):

1. Araştırma sorusunun belirlenmesi: Araştırma sorusu belirlenir, araştırma süreci ve zamanlama belirlenir.

2. Protokol (araştırmanın tasarımı, kavramsal temeli, ölçütleri vb. planlanması): Değerlendirme araçları, dahil etme ve dışlama kriterleri ortaya konulur. 
Kıran, Macun, Argın \& Ulutaş - Çukurova Üniversitesi Eğitim Fakültesi Dergisi, 50(2), 2021, 1154-1183

3. Bilgi alma ve çalışma seçimi (elektronik vb. kaynakların taranması): Seçme ölçütlerine göre kaynaklar taranır, araştırmaya dahil edilecek çalışmalar kayıt altına alınır, okuma ve incelemeleri yapılır.

4. Kodlama (çalışmaların tanımlanması ve sınıflandırılması): Araştırmalar oluşturulan kontrol listesine göre kodlanır, birden fazla araştırmacı tarafından kodlama yapılır. Oluşturulan kodlar karşılaştırılır.

5. Kalite değerlendirmesi (araştırmaya alınacak çalışmaların elemeden geçirilmesi): Çalışmalar amaç, yöntem, bulgular ve tartışma bakımından güçlü ve zayıf yönleri karşılaştırılır, çalışmaya dahil edilme ve dışlanma nedenleri açıklanır.

6. Sentez (çalışmaların sonuçlarının birleştirilmesi): Çalışmalar amaç, yöntem ve bulgular açısından bir araya getirilerek bütünleştirilir.

7. Rapor yazımı ve yayımlama: Çalışma yayınlanacak formata uygun olarak yazılır ve diğer araştırmacılarla paylaşılmak üzere yayınlanır.

$\mathrm{Bu}$ çalışmanın hazırlanmasında "Sistematik derleme ve meta-analiz çalışmalarının raporlandırılmasında göz önünde bulundurulması gereken maddelerle ilgili kontrol listesi" (Preferred reporting items for sistematik reviews and metaanalyses statement-PRISMA) kullanılmıştır (The PRISMA Statement, 2020).

\section{Örneklemin Belirlenmesi}

Araştırmada veri tabanları taranırken herhangi bir yıl kısıtlaması yapılmadan taramalar yapılmış ve Mart ve Nisan 2020 tarihi süresince Montessori ile ilgili tüm çalışmalara ulaşılmıştır. Araştırmaya alınacak çalışmaların belirlenmesinde bazı ölçütler belirlenmiştir. Türkiye'de yapılan İngilizce ve Türkçe çalışmaların araştırmaya alınmasına, Türkiye dışında yapılan araştırmaların dili Türkçe dahi olsa değerlendirmeye alınmamasına, araştırma kapsamında sadece dergi makalelerinin incelenmesine ve bildiriler, tezler, kitap bölümü vb. eserlerin araştırma dışında bırakılmasına karar verilmiştir.

Araştırmada makalelere ulaşabilmek amacıyla Google Scholar, Dergipark, TR Dizin veri tabanları taranmıştır. Anahtar kelimeler arasındaki ortak alanyazını tanımlamak için anahtar kelimelerin arasında "ve" kullanılmış, "Okul öncesi ve Montessori”, "Erken çocukluk ve Montessori" anahtar kelimeleri ile tarama yapılmıştır. Google Akademikte ise gelişmiş tarama bölümü kullanılarak; kelime grubunu aynen içeren kısmına Okul öncesi/Erken çocukluk; kelimelerinin tümünü içeren kısma ise "Montessori" yazıımıştır. Bu taramalar sonucunda 10-20 Nisan tarih aralığında Dergipark veri tabanından "Okul öncesi” ve Montessori" taramasında 108 sonuç, "Erken çocukluk ve Montessori" taramasında 57 sonuç olmak üzere toplam 165 sonuca erişilmiştir. TR Dizin veri tabanında "Okul öncesi ve Montessori" taramasında 14 sonuç, "Erken çocukluk ve Montessori" taramasında dört sonuç olmak üzere toplam 18 sonuca erişilmiştir. Bu veri tabanlarından ulaşılamayan dergi makaleleri ise Google Akademik taraması yapılarak "Okul öncesi ve Montessori" taramasında 1200, "Erken çocukluk" ve "Montessori" taramasında 700 sonuç olmak üzere toplam 1900 sonuca ulaşılmıştır. Veri tabanlarından erişilen makalelerin başlık taramaları yapılarak incelenmek üzere 81 makale belirlenmiştir. 81 makale arasından bazı makalelerin hem İngilizce hem de Türkçe başlıklarının olduğu ve bu makalelerin tekrarlandığı belirlenerek sayı 75’e düşürülmüştür.

Makalelerin seçimi iki adımda gerçekleşmiştir: Birinci adımda yapılan taramalar sonucunda elde edilen çalışmaların başlıkları ve özetleri ilişkili olma durumuna göre taranmıştır. İkinci adımda ise araştırmaların tam metin incelemeleri yapılarak yürütülen araştırmaya alınma ölçütlerini karşılayıp karşılamadıkları belirlenmiştir. Değerlendiriciler arasındaki tutarsızlıklar tartışma yoluyla veya nihai kararı veren araştırma metodoloğuna danışılarak çözülmüştür.

75 araştırmanın özetleri incelenerek bir tez, bir konferans bildirisi araştırmadan çıkarılmıştır. 73 makaleden 17 derleme makale, bir ilköğretim dönemini kapsayan makale, 20 alan dışı makale, dört farklı ülke örnekleri ve erişilemeyen bir makale olmak üzere 44 makale ayıklanmıştır. Kalan 29 makale her bir 
Kıran, Macun, Argın \& Ulutaş - Çukurova Üniversitesi Eğitim Fakültesi Dergisi, 50(2), 2021, 1154-1183

araştırmacı tarafından ayrı ayrı kanıt ağırlığı tablosunda incelenmek üzere araştırmaya alınmıştır. Yedi makale ise araştırmacılar tarafından kanıt ağırlığı tablosunda incelenmiş ve puan ortalamaları düşük çıktığı için elenmiş̧tir ve kalan 22 makale ele alınmıştır. Tablo 1'de araştırmaya alınan çalışmaların seçim ölçütleri verilmiştir.

Tablo 1.

Seçim Ölçütleri

\begin{tabular}{ll}
\hline Konu & $\begin{array}{l}\text { Erken çocukluk döneminde Montessori yöntemi ile ilgili yapılan } \\
\text { araştırmalar }\end{array}$ \\
\hline Yöntem & Nicel, nitel ve karma araştırmalar \\
\hline Çalışma grubu & $\begin{array}{l}\text { Okul öncesi dönemi çocukları, okul öncesi dönem çocuklarının aileleri, } \\
\text { okul öncesi öğretmenleri, okul öncesi öğretmen adayları }\end{array}$ \\
\hline Dil özellikleri & Türkiye ile sınırı İngilizce ve Türkçe dillerinde yayımlanmış makaleler \\
\hline Yayımlanma tarihi & 20 Nisan 2020 tarihinden önce yayımlanmış makaleler \\
\hline
\end{tabular}

Tablo 1'e göre sistematik derlemeye alınacak çalışmaların konu, yöntem, çalışma grubu, dil özellikleri ve yayımlanma tarihi ölçütlerinin kullanıldığı görülmektedir.

\section{Veri Analizi}

Çalışmada 29 makale derinlemesine incelenmiş ve her bir makale için kanıt ağırlı̆̆ı tablosu (Weight of Evidence/WoE) oluşturulmuştur. Araştırmalar üç alt boyutta incelenmiş ve 0-hiç, 1-biraz, 2-çoğunlukla, 3-tamamen olmak üzere 0'dan 3'e kadar puanlanıp toplam WoE puanı elde edilmiştir. WoE A'da çalışmanın genel kalitesi, WoE B'de yöntemsel uygunluk ve seçilen araştırma desenleri, WoE C'de ise bulguların uygunluğu/yeterliliği ve araştırmanın etikliği değerlendirmelerinden edinilen puanlar değerlendirilmiştir. WoE D ise ortalama kanıt ağırlığı değerini vermektedir.

WoE A başlı̆ının altında;

- Araşırımanın amaçları ve hedefleri açıkça belirtilmiştir.

- Çalışmanın kavramsal çerçevesi yeterli ve açık bir şekilde tanımlanmıştır.

- Araştırmanın deseni araştırma sorularına uygundur.

- Çalışmanın içeriği açıkça tanımlanmıştır.

- Örnekleme stratejisi yeterli ve açık bir şekilde tanımlanmıştır.

- Veri toplama yeterli ve açık bir şekilde tanımlanmıştır.

- Verilerin analizi yeterli ve açık bir şekilde belirtilmiştir.

- Bulgular verilerle desteklenmektedir.

- Iddialar bulgulara dayanmaktadır.

WoE B başlı̆ıının altında;

- Araştırma yöntemsel olarak uygundur.

WoE C başlı̆ının altında;

- Araştırma bulguları araştırmanın amacıyla uygundur.

- Araştırma bulguları yeterlidir, maddeleri yer almaktadır (Bereczkia ve Kárpáti, 2018).

Araştırmada kanıt ağırlığı tablosuna göre ortalaması 1.5 puan ve altında değer verilen yedi çalışma elenmiştir. Elenen çalışmalar yalnızca kanıt ağırlığı ölçütlerindeki maddeler doğrultusunda değerlendirilmiştir. Tüm bu aşamalar sonucunda ortaya çıkan PRISMA Akış Diyagramı Şekil 1'de verilmiştir. 


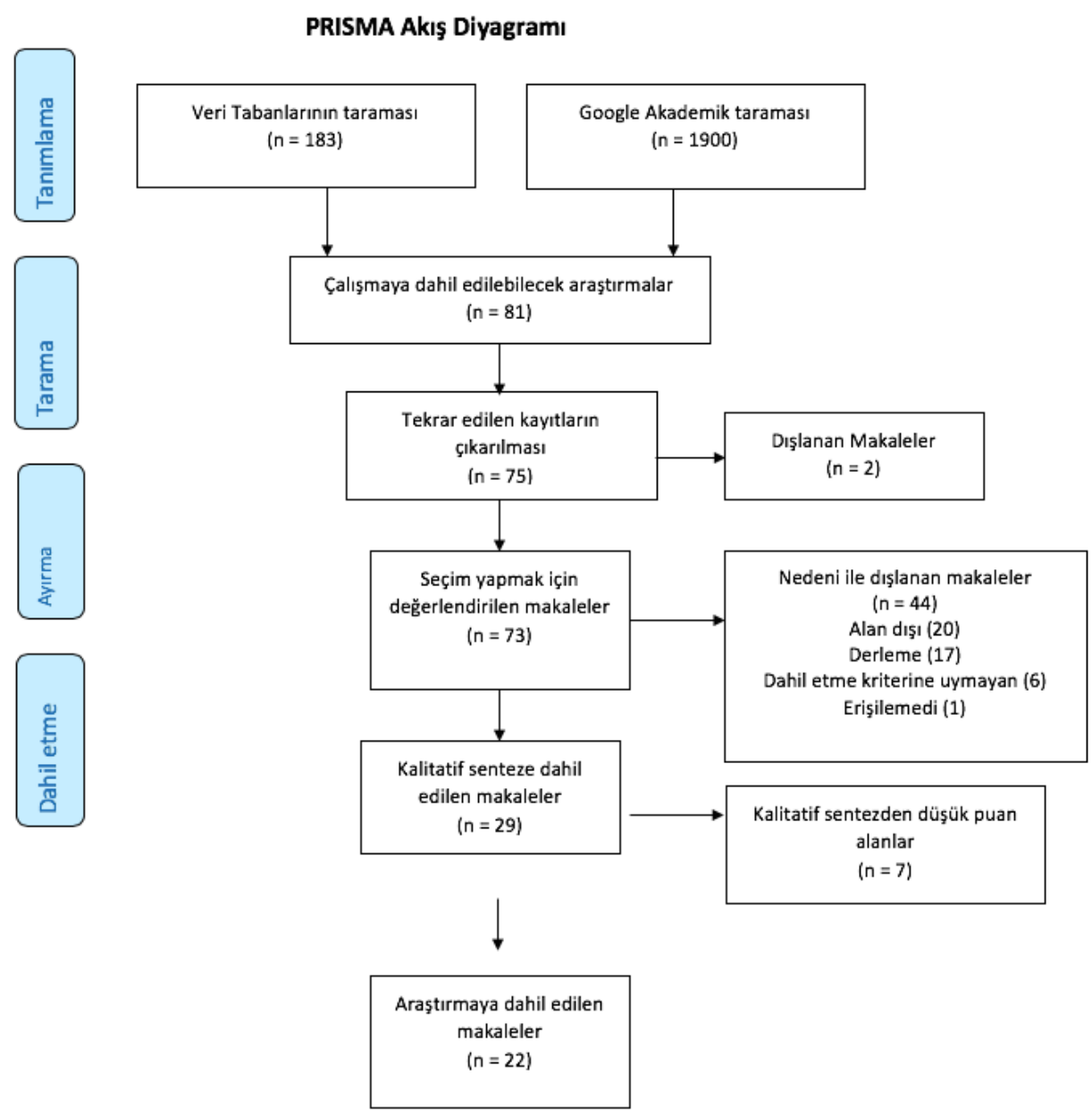

Şekil 1. PRISMA Akış Diyagramı

Bulgular

Sistematik değerlendirme sürecindeki incelemeler sonucunda toplam 22 çalışma belirlenmiştir. Tablo 2'de araştırma kapsamında incelenen çalışmalar ve gerçekleştirilme amacı Tablo 2'de verilmiştir.

Tablo 2.

Araştırmada incelenen Çalışmaların Gerçekleştirilme Amacı

\begin{tabular}{|c|c|c|c|c|}
\hline & Yazar & Amaç & Ölçme Aracı & Örneklem \\
\hline 1 & $\begin{array}{l}\text { Aral, Yıldız } \\
\text { Bıçakcı, Yurteri } \\
\text { Tiryaki, Çetin } \\
\text { Sultanoğlu \& } \\
\text { Şahin, } 2015\end{array}$ & $\begin{array}{l}\text { Montessori yaklaşımına dayalı } \\
\text { eğitimin çocukların gelişim alanlarına } \\
\text { etkisi incelenmiştir. }\end{array}$ & ÖDGG-4, GP-3 & 93 çocuk \\
\hline 2 & Buldur, 2019 & $\begin{array}{l}\text { Okul öncesi eğitimine devam eden ve } \\
\text { Montessori eğitimi alan } 48-72 \text { aylık } \\
\text { çocukların bilimsel süreç becerileri } \\
\text { incelenmiştir. }\end{array}$ & $\begin{array}{l}\text { Okul Öncesi } \\
\text { Öğrencilerine Yönelik } \\
\text { Temel Beceri Ölçeği } \\
\text { (OÖYTBÖ) }\end{array}$ & 60 çocuk \\
\hline
\end{tabular}


Kıran, Macun, Argın \& Ulutaş - Çukurova Üniversitesi Eğitim Fakültesi Dergisi, 50(2), 2021, 1154-1183

\begin{tabular}{|c|c|c|c|c|}
\hline 3 & $\begin{array}{l}\text { Çakır, Altun } \\
\text { Yalçın \& Yalçın, } \\
2019\end{array}$ & $\begin{array}{l}\text { Okul öncesi öğretmen adaylarının } \\
\text { yaratıcılık becerilerinin gelişimleri } \\
\text { üzerinde Montessori yaklaşımı temelli } \\
\text { STEM etkinliklerinin etkisi } \\
\text { incelenmiştir. }\end{array}$ & $\begin{array}{l}\text { “Ne Kadar } \\
\text { Yaratıcısınız?" ölçeği, } \\
\text { "Yarı yapılandırılmış } \\
\text { mülakat formu" }\end{array}$ & $\begin{array}{c}50 \text { öğretmen } \\
\text { adayı }\end{array}$ \\
\hline 4 & Dereli, 2017 & $\begin{array}{l}\text { Okul öncesi eğitime devam eden 4-5 } \\
\text { yaş grubu çocukların psikososyal } \\
\text { gelişimleri ve sosyal problem çözme } \\
\text { becerileri üzerinde Montessori eğitim } \\
\text { programının etkisi incelenmiştir. }\end{array}$ & $\begin{array}{l}\text { Okul Öncesi Çocuklar } \\
\text { için Psikolojik Gözlem } \\
\text { Formu Ölçeği ve Wally } \\
\text { Çocuk Sosyal Problem } \\
\text { Çözme Dedektif Oyun } \\
\text { Ölçeği }\end{array}$ & 160 çocuk \\
\hline 5 & Kayılı \& Arı, 2016 & $\begin{array}{l}\text { Çocukların duygularını anlama ve } \\
\text { sosyal problemleri çözme becerileri } \\
\text { üzerinde Montessori yönteminin } \\
\text { etkisini incelemek amaçlanmıştır. }\end{array}$ & $\begin{array}{l}\text { Wally Feelings Test ve } \\
\text { Wally Social Problem } \\
\text { Solving Test }\end{array}$ & 53 çocuk \\
\hline 6 & $\begin{array}{l}\text { Yücesan \& } \\
\text { Özyürek, } 2017\end{array}$ & $\begin{array}{l}\text { Okul öncesi dönemde Montessori } \\
\text { eğitimi alan ve almayan çocukların } \\
\text { problem davranışları incelenmiştir. }\end{array}$ & $\begin{array}{l}\text { Anaokulu ve Anasınıfı } \\
\text { Davranış Ölçeği (PKBS- } \\
\text { 2) }\end{array}$ & 60 çocuk \\
\hline
\end{tabular}

\begin{tabular}{|c|c|c|c|c|}
\hline 7 & $\begin{array}{l}\text { Güven, Gültekin } \\
\text { \& Dedeoğlu, } \\
2020\end{array}$ & $\begin{array}{l}\text { Milli Eğitim Bakanlığı okul öncesi } \\
\text { eğitim programı ve Montessori } \\
\text { yaklaşımına göre eğitim almış çocuklar } \\
\text { arasında sudoku çözme becerileri } \\
\text { arasında fark olup olmadığı } \\
\text { incelenmiştir. }\end{array}$ & $\begin{array}{l}\text { Sudoku Becerileri } \\
\text { Ölçeği }\end{array}$ & 118 çocuk \\
\hline 8 & Kayılı \& Arı, 2011 & $\begin{array}{l}\text { Montessori yönteminin okul öncesi } \\
\text { çocukların ilköğretime hazır olma } \\
\text { durumları üzerindeki etkisi } \\
\text { incelenmiştir. }\end{array}$ & $\begin{array}{l}\text { Metropolitan Okul } \\
\text { Olgunluğu Testi, PKBS } \\
\text { Okul Öncesi ve } \\
\text { Anaokulu Davranış } \\
\text { Ölçeği, FTF-K Dikkat } \\
\text { Toplama Becerileri Testi }\end{array}$ & 50 çocuk \\
\hline 9 & $\begin{array}{l}\text { Toran \& Temel, } \\
2014\end{array}$ & $\begin{array}{l}\text { 4-6 yaş arası çocukların kavram } \\
\text { edinimleri üzerinde Montessori } \\
\text { Yaklaşımının etkisi incelenmiştir. }\end{array}$ & $\begin{array}{l}\text { Bracken Temel Kavram } \\
\text { Ölçeği Gözden } \\
\text { Geçirilmiş Formu }\end{array}$ & 48 çocuk \\
\hline 10 & Kayılı, 2016a & $\begin{array}{l}\text { Montessori yaklaşımının } 4-5 \text { yaş } \\
\text { çocukların bilişsel temposu üzerine } \\
\text { etkisini incelemek amaçlanmıştır. }\end{array}$ & $\begin{array}{l}\text { Okul öncesi için Kansas } \\
\text { Yansıma-Immpulsivite } \\
\text { Ölçeği }\end{array}$ & 60 çocuk \\
\hline 11 & Aydoğan, 2016 & $\begin{array}{l}\text { Montessori eğitimi alan okul öncesi } \\
\text { çocukların dil gelişimi incelenmiştir. }\end{array}$ & $\begin{array}{l}\text { Descoeudres Dil Testi, } \\
\text { Sözlük ve Dil Testi, } \\
\text { Peabody Resimli Kelime } \\
\text { Bilgisi Testi }\end{array}$ & 35 çocuk \\
\hline 12 & $\begin{array}{l}\text { Kayılı, Koçyiğit \& } \\
\text { Erbay, } 2009\end{array}$ & $\begin{array}{l}\text { Beş - altı yaş çocuklarının alıcı dil } \\
\text { becerilerinde Montessori yönteminin } \\
\text { etkisi incelenmiştir. }\end{array}$ & $\begin{array}{l}\text { Peabody Resim-Kelime } \\
\text { Testi }\end{array}$ & 40 çocuk \\
\hline 13 & $\begin{array}{l}\text { Noyat, İnam } \\
\text { Karahan \& } \\
\text { Alakuş, } 2019\end{array}$ & $\begin{array}{l}\text { Okul öncesi dönemde eğitim gören } \\
\text { çocukların yaratıcılık gelişimlerinde } \\
\text { Montessori yaklaşımının etkisi } \\
\text { incelenmiştir. }\end{array}$ & Gözlem formu & 80 çocuk \\
\hline
\end{tabular}


Kıran, Macun, Argın \& Ulutaş - Çukurova Üniversitesi Eğitim Fakültesi Dergisi, 50(2), 2021, 1154-1183

\begin{tabular}{|c|c|c|c|c|}
\hline 14 & $\begin{array}{l}\text { Temel, Kaynak, } \\
\text { Paslı, Demir \& } \\
\text { Çemrek, } 2016\end{array}$ & $\begin{array}{l}\text { Montessori eğitim kurumlarında } \\
\text { eğitim alan çocukların görsel algı ve } \\
\text { çizim becerileri arasındaki ilişki } \\
\text { incelenmiştir. }\end{array}$ & $\begin{array}{l}\text { Bender-Gestalt Görsel } \\
\text { Algı Testi, Goodenough- } \\
\text { Harris Adam Çizme } \\
\text { Testi }\end{array}$ & 83 çocuk \\
\hline 15 & $\begin{array}{l}\text { Yıldırım, Akman } \\
\text { \& Alabay, } 2012\end{array}$ & $\begin{array}{l}\text { Okul öncesinde eğitim alan çocukların } \\
\text { görsel algılama davranışlarında } \\
\text { Montessori ve mandala eğitiminin } \\
\text { etkisi incelenmiştir. }\end{array}$ & Frostig Görsel Algı Testi & 36 çocuk \\
\hline 16 & $\begin{array}{l}\text { Yıldız \& Çağdaş, } \\
2019\end{array}$ & $\begin{array}{l}\text { Anneleri Montessori Anne } \\
\text { Destek Eğitimi alan 4-5 yaş çocukların } \\
\text { matematik ve günlük yaşam becerileri } \\
\text { incelenmiştir. }\end{array}$ & $\begin{array}{l}\text { Temel Okul Becerileri } \\
\text { Envanteri-3'ün } \\
\text { Matematik ve Günlük } \\
\text { Yaşam Becerileri" alt } \\
\text { testleri }\end{array}$ & 19 çocuk \\
\hline 17 & $\begin{array}{l}\text { Yıldızbaş \& } \\
\text { Aslıyüksek, } 2016\end{array}$ & $\begin{array}{l}\text { Montessori eğitim programının 4-5 } \\
\text { yaş grubu çocukların motor beceri, } \\
\text { görsel algı, bellek, el göz } \\
\text { koordinasyonu ve küçük kas } \\
\text { becerilerini kazandırmada etkililiği } \\
\text { incelenmiştir. }\end{array}$ & $\begin{array}{l}\text { Gesell Gelişim Testi, } \\
\text { Denver II Gelişimsel } \\
\text { Tarama Testi }\end{array}$ & 40 çocuk \\
\hline 18 & $\begin{array}{l}\text { Yüksek Usta \& } \\
\text { Tezel Şahin, } \\
2019\end{array}$ & $\begin{array}{l}\text { Montessori anaokuluna devam eden } \\
\text { çocuklar ile devlet anaokuluna devam } \\
\text { eden çocukların, Dünya ve coğrafi } \\
\text { kavramlara yönelik farkındalıklarının } \\
\text { tespit edilmesi amacıyla } \\
\text { gerçekleştirilmiştir. }\end{array}$ & Çocuk Görüşme Formu & 32 çocuk \\
\hline 19 & $\begin{array}{l}\text { Zembat, Günşen } \\
\text { \& Gök Çolak, } \\
2019\end{array}$ & $\begin{array}{l}\text { Okul öncesi eğitimi şekillendiren } \\
\text { düşünürler ve onların temsil ettiği } \\
\text { yaklaşımlar hakkında okul öncesi } \\
\text { öğretmenlerinin görüşlerinin } \\
\text { belirlenmesi amaçlanmıştır. }\end{array}$ & $\begin{array}{l}\text { Yarı yapılandırılmış } \\
\text { görüşme formu }\end{array}$ & $\begin{array}{l}20 \text { okul } \\
\text { öncesi } \\
\text { öğretmeni }\end{array}$ \\
\hline 20 & $\begin{array}{l}\text { Atlı, Korkmaz, } \\
\text { Taştepe \&Köksal } \\
\text { Akyol, } 2016\end{array}$ & $\begin{array}{l}\text { Montessori yaklaşımı uygulayan okul } \\
\text { öncesi öğretmenlerinin görüşlerinin } \\
\text { belirlemek amaçlanmıştır. }\end{array}$ & $\begin{array}{l}\text { Yarı yapılandırılmış } \\
\text { görüşme formu }\end{array}$ & $\begin{array}{c}9 \text { okul } \\
\text { öncesi } \\
\text { öğretmeni }\end{array}$ \\
\hline 21 & Şahin Sak, 2014 & $\begin{array}{l}\text { Okul öncesi öğretmen adaylarının } \\
\text { Montessori ve Reggio Emilia yaklaşımı } \\
\text { ile ilgili görüşleri belirlenmeye } \\
\text { çalışılmıştır. }\end{array}$ & Yansıtma raporları & $\begin{array}{c}30 \text { öğretmen } \\
\text { adayı }\end{array}$ \\
\hline 22 & $\begin{array}{l}\text { Bozkurt, } \\
\text { Kölemen, } \\
\text { Abanoz \& } \\
\text { Ulutaş, } 2019\end{array}$ & $\begin{array}{l}\text { Montessori eğitimi alan çocukların } \\
\text { ebeveynlerinin Montessori eğitimi } \\
\text { algısını tespit etmek amacıyla } \\
\text { gerçekleştirilmiştir. }\end{array}$ & $\begin{array}{l}\text { Ebeveynlerin } \\
\text { Montessori Eğitim } \\
\text { Yaklaşımına İlişkin } \\
\text { Görüşlerini Belirleme } \\
\text { Formu }\end{array}$ & 25 ebeveyn \\
\hline
\end{tabular}

Tablo 2'ye göre araştırmaların gerçekleştirilme amaçları incelendiğinde; ebeveyn boyutunda; ebeveynlerin Montessori yöntemine yönelik algılarının incelendiği (Bozkurt vd., 2019) belirlenmiştir. Çocuk boyutunda; çocukların coğrafi kavram farkındalıkları (Yüksek Usta \& Tezel Şahin, 2019), kavram kazanımları (Toran \& Temel, 2014), görsel algı becerileri (Temel vd., 2016; Yıldızbaş \& Aslıyüksek, 2016), çizim becerileri (Temel vd., 2016), bilimsel süreç becerileri (Buldur, 2019), sudoku çözme becerileri (Güven, vd., 2020), dil gelişimi (Aydoğan, 2016), psiko sosyal gelişim (Dereli, 2017), çocukların 
Kıran, Macun, Argın \& Ulutaş - Çukurova Üniversitesi Eğitim Fakültesi Dergisi, 50(2), 2021, 1154-1183

ilköğretime hazır oluşları (Kayılı \& Arı, 2011), sosyal problem çözme becerileri (Dereli, 2017; Kayılı \& Arı, 2016), çocukların problem davranışlarının incelenmesi (Yücesan \& Özyürek, 2017), motor becerileri (Yıldızbaş \& Aslıyüksek, 2016), bellek (Yıldızbaş \& Aslıyüksek, 2016), el-göz koordinasyonu (Yıldızbaş \& Aslıyüksek, 2016), küçük kas becerileri (Yıldızbaş \& Aslıyüksek, 2016), alıcı dil becerileri (Kayılı vd., 2009), görsel algı (Yıldırım, vd., 2012), yaratıcılık gelişimleri (Noyat, vd., 2019), bilişsel tempo (Kayılı, 2016a), duygularını anlama becerisi (Kayılı \& Arı, 2016) ve annelere verilen Montessori destek eğitiminin çocukların matematik ve günlük yaşam becerileri üzerindeki etkisi (Yıldız \& Çağdaş, 2019) üzerinde çalışıldığı görülmektedir. Öğretmen adayları boyutunda; programın adayların yaratııılık becerilerine etkisi (Çakır, vd., 2019), adayların Montessori ve Reggio Emilia yaklaşımları hakkındaki görüşleri (Şahin Sak, 2014) üzerinde çalışıldığı görülmektedir. Öğretmen boyutunda ise; öğretmenlerin okul öncesi düşünürleri ve yaklaşımlar hakkındaki görüşleri (Zembat, vd., 2019) ve öğretmenlerin Montessori yaklaşımı hakkındaki görüşleri (Atlı, vd., 2016) üzerine çalışmalar yapılmıştır. Çalışmaların örnekleme göre dağııımı Tablo 3'te verilmiştir.

Tablo 3.

Çalışmaların Örnekleme Göre Dağılımı

\begin{tabular}{llr}
\hline Örneklem & Makaleler & $\mathrm{f}$ \\
\hline Çocuk & Aral vd., 2015; Aydoğan, 2016; Buldur, 2019; Dereli, 2017; & 17 \\
& Güven vd., 2020; Kayılı \& Arı, 2011; Kayılı \& Arı, 2016; & \\
& Kayılı, 2016a; Kayılı vd., 2009; Noyat vd., 2019; Temel vd., & \\
& 2016; Toran \& Temel, 2014; Yıldıım vd., 2012; Yıldız \& & \\
& Çağdaş, 2019; Yıldızbaş \& Aslıyüksek, 2016; Yücesan \& & \\
& Özyürek, 2017; Yüksek Usta \& Tezel Şahin, 2019 & 2 \\
\hline Okul Öncesi Öğretmeni & Atıı vd., 2016; Zembat vd., 2019 & 1 \\
\hline Ebeveyn & Bozkurt vd., 2019 & 2 \\
\hline Öğretmen Adayı & Çakır vd., 2019; Şahin Sak, 2014 & 22 \\
\hline Toplam & & \\
\hline
\end{tabular}

Tablo 3'e göre araştırmaların örneklem grupları bir makalede aile (\%4,55), 17 makalede çocuk $(\% 77,27)$, iki makalede öğretmen $(\% 9,09)$ ve iki makalede de öğretmen adaylarından $(\% 9,09)$ oluşmaktadır. Çalışmaların araştırma desenine göre dağııımı Tablo 4'te verilmiştir.

Tablo 4.

Çalışmaların Araştırma Desenine Göre Dağııımı

\begin{tabular}{lllc}
\hline Araştırma Yöntemi & Makaleler & $f$ \\
\hline Nicel & Yarı Deneysel & Dereli, 2017; Yıldızbaş \& Aslıyüksek, 2016 & 2 \\
\hline & Boylamsal & Buldur, 2019 & 1 \\
\hline & Illişkisel Tarama & Temel vd., 2016 & 1 \\
\hline & Tarama & Yücesan \& Özyürek, 2017 & 1 \\
\hline \multirow{2}{*}{ Deneysel } & Aral vd., 2015; Aydoğan, 2016; Güven vd., 2020; Kayılı \& Arı, 2011; & 10 \\
& & Kayılı \& Arı, 2016; Kayılı vd., 2009; Kayılı, 2016a; Toran \& Temel, 2014; & \\
& & Yılıııı vd., 2012; Yıldız \& Çağdaş, 2019 & 1 \\
\hline Nitel & Olgubilim & Bozkurt vd., 2019; Zembat vd., 2019 & 5 \\
\hline & Belirtilmemiş & Atlı vd., 2016; Noyat vd., 2019; Şahin Sak, 2014; Yüksek Usta \& Tezel & 5 \\
& Şahin, 2019 & 1 \\
\hline Karma & Çakır vd., 2019 & 22 \\
\hline Toplam & &
\end{tabular}

Tablo 4'e göre yapılan sistematik derlemeye alınan çalışmaların 15'i nicel, altısı nitel ve biri karma desenle gerçekleştirilmiştir. Şekil 2'de çalışmaya alınan araştırmaların desenlerine göre dağılımı verilmiştir. 


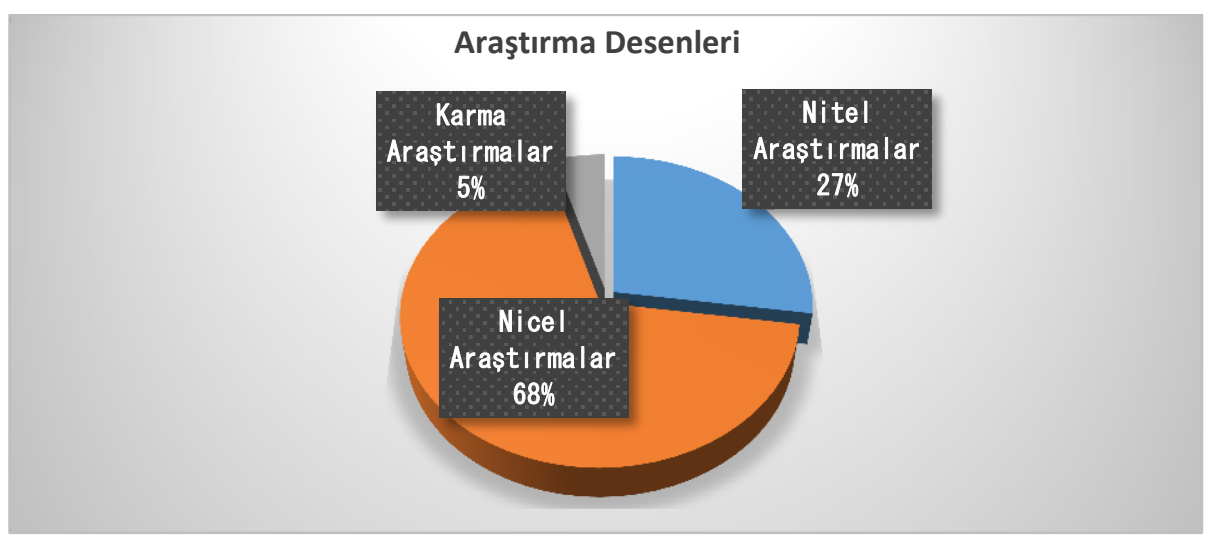

Şekil 2. Çalışmaların Araştırma Desenlerine Göre Dağılımı

Tablo 5'te sistematik derlemeye alınan çalışmaların yayın yılına göre dağııımı verilmiştir.

Tablo 5

Çalıșmaların Yayın Yılına Göre Dağı̆ıımı

\begin{tabular}{|c|c|c|}
\hline$\overline{Y l l}$ & Makaleler & $f$ \\
\hline 2009 & Kayılı, Koçyiğit \& Erbay, 2009 & 1 \\
\hline 2011 & Kayılı \& Arı, 2011 & 1 \\
\hline 2012 & Yıldırım, Akman \& Alabay, 2012 & 1 \\
\hline 2014 & Şahin Sak, 2014; Toran \& Temel, 2014 & 2 \\
\hline 2015 & Aral, Yıldız Bıçakçı, Yurteri Tiryaki, Çetin Sultanoğlu \& Şahin, 2015 & 1 \\
\hline 2016 & $\begin{array}{l}\text { Atlı, Korkmaz, Taştepe \& Köksal Akyol, 2016; Aydoğan, 2016; Kayılı, 2016a; Kayılı \& } \\
\text { Arı, 2016; Temel, Kaynak, Paslı, Demir \& Çemrek, 2016; Yıldızbaş \& Aslıyüksek, } \\
2016\end{array}$ & 6 \\
\hline 2017 & Dereli, 2017; Yücesan \& Özyürek, 2017 & 2 \\
\hline 2019 & $\begin{array}{l}\text { Bozkurt, Kölemen, Abanoz \& Ulutaş, 2019; Buldur, 2019; Çakır, Altun Yalçın \& } \\
\text { Yalçın, 2019; Noyat, Inam Karahan \& Alakuş, 2019; Yıldız \& Çağdaş, 2019; Yüksek } \\
\text { Usta \& Tezel Şahin, 2019; Zembat, Günşen \& Gök Çolak, 2019 }\end{array}$ & 7 \\
\hline 2020 & Güven, Gültekin \& Dedeoğlu, 2020 & 1 \\
\hline Toplam & & 22 \\
\hline
\end{tabular}

Tablo 5'e göre yedi makale ile en fazla araştırmanın 2019 yılında yayınlandığı görülmektedir. 2016 yılında yayımlanan altı, 2014 ve 2017 yıllarında yayımlanan iki ve 2009, 2011, 2012, 2015, ve 2020 yıllarında yayınlanan birer makale araştırmaya alınmıştır. Şekil 3'te çalışmaların yıllara göre dağııımı verilmiştir. 


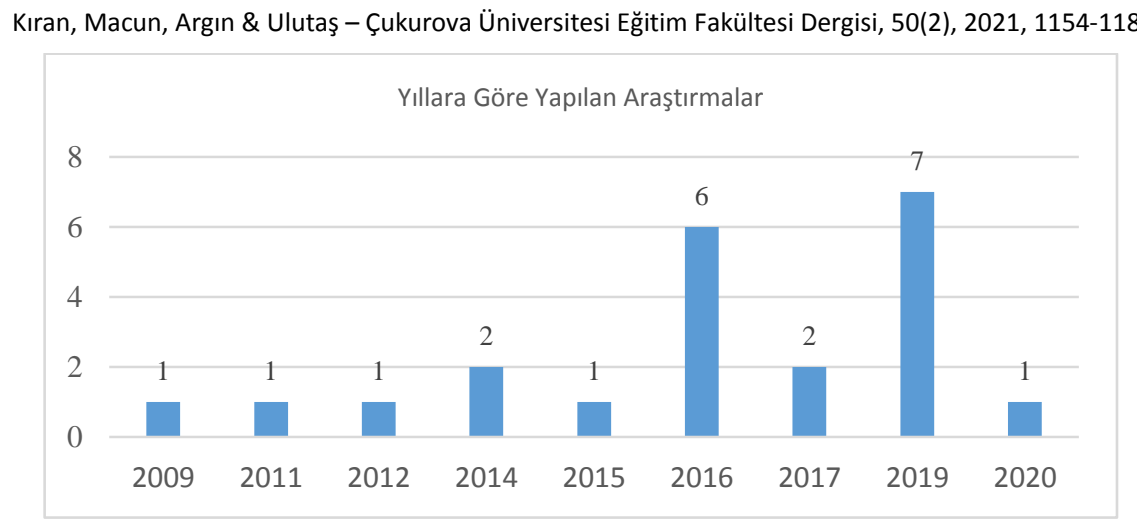

Şekil 3. Çalışmaların Yıllara Göre Dağılımı

Tablo 6'da sistematik derlemeye alınan çalışmalarda kullanılan veri toplama araçları verilmiştir.

Tablo 6

Çalışmalarda Kullanılan Veri Toplama Araçları ve Kullanıldığı Çalışmalar

\begin{tabular}{|c|c|c|}
\hline Veri Toplama Araçları & Makaleler & $f$ \\
\hline Görüşme & $\begin{array}{l}\text { Yarı Yapılandırılmış Görüşme (Bozkurt, Kölemen, Abanoz \& Ulutaş, } \\
\text { 2019; Çakır vd., 2019; Yüksek Usta \& Tezel Şahin, 2019; Zembat } \\
\text { vd., 2019; Atlı vd., 2016) }\end{array}$ & 5 \\
\hline Gözlem formu & (Noyat vd., 2019) & 1 \\
\hline Yansitma raporu & (Şahin Sak, 2014) & 1 \\
\hline \multirow[t]{22}{*}{ Ölçek } & Sudoku Becerileri Ölçeği (Güven, Gültekin \& Dedeoğlu, 2020) & 1 \\
\hline & Descoeudres Dil Testi(Aydoğan, 2016) & 1 \\
\hline & Bracken Temel Kavram Ölçeği (Toran \& Temel, 2014) & 1 \\
\hline & Sözlük ve Dil Testi (Aydoğan, 2016) & 1 \\
\hline & Denver II Gelişimsel Tarama Testi (Yıldızbaş \& Aslıyüksek, 2016) & 1 \\
\hline & $\begin{array}{l}\text { Peabody Resimli Kelime Bilgisi Testi (Aydoğan, 2016; Kayılı, } \\
\text { Koçyiğit \& Erbay, 2009) }\end{array}$ & 2 \\
\hline & Gesell Gelişim Testi (Yıldızbaş \& Aslıyüksek, 2016) & 1 \\
\hline & Metropolitan Okul Olgunluğu Testi (Kayılı \& Arı, 2011) & 1 \\
\hline & $\begin{array}{l}\text { PKBS Okul Öncesi ve Anaokulu Davranış Ölçeği (Kayılı \& Arı, 2011; } \\
\text { Yücesan \& Özyürek, 2017) }\end{array}$ & 2 \\
\hline & FTF-K Dikkat Toplama Becerileri Testi (Kayılı \& Arı, 2011) & 1 \\
\hline & Okul Öncesi İçin Kansas Yansıma-İmpulsivite Ölçeği (Kayılı, 2016a) & 1 \\
\hline & Bender-Gestalt Görsel Algı Testi (Temel vd., 2016) & 1 \\
\hline & Temel Okul Becerileri Envanteri-3 (Yıldız \& Çağdaş, 2019) & 1 \\
\hline & Wally Feelings Test (Kayılı \& Arı, 2016) & 1 \\
\hline & Wally Social Problem Solving Test (Kayılı \& Arı, 2016; Dereli, 2017) & 2 \\
\hline & Goodenough-Harris Adam Çizme Testi (Temel vd., 2016) & 1 \\
\hline & $\begin{array}{l}\text { Okul Öncesi Öğrencilerine Yönelik Temel Beceri Ölçeği (OÖYTBÖ) } \\
\text { (Buldur, 2019) }\end{array}$ & 1 \\
\hline & $\begin{array}{l}\text { Okul Öncesi Çocuklar için Psikolojik Gözlem Formu Ölçeği (Dereli, } \\
\text { 2017) }\end{array}$ & 1 \\
\hline & $\begin{array}{l}\text { Öğrenmenin Değerlendirilmesi için Gelişimsel Göstergeler } 4 \\
\text { (ÖDGG-4) (Aral vd., 2015) }\end{array}$ & 1 \\
\hline & Gelişimsel Profil 3 (GP3) (Aral vd., 2015) & 1 \\
\hline & Ne Kadar Yaratıcısınız?” Ölçeği (Çakır vd., 2019) & 1 \\
\hline & Frostig Görsel Algı Testi (Yıldırım vd., 2012) & 1 \\
\hline
\end{tabular}


Tablo 6'ya göre araştırma kapsamına alınan beş çalışmada yarı yapılandırılmış görüşme formu, birer çalışmada ise gözlem formu ve yansıtma raporu kullanılmıştır. Nicel ve karma çalışmalarda ise 22 farklı ölçek kullanılmıştır. Görüşmelerin tamamının yarı yapılandırılmış görüşme formu aracılığı ile yapıldığı dikkat çekmektedir. Ayrıca çalışmalar genellikle tek ölçme aracı kullanılarak gerçekleştirilmiştir. Tablo 7 'de çalışmalarda araştırılan konular ve frekans değerleri verilmiştir.

Tablo 7

Çalışmalarda Araştırılan Konular

\begin{tabular}{llc}
\hline Araştırılan Konu & Makaleler & $f$ \\
\hline Görüş/Algı & Atlı vd., 2016; Bozkurt vd., 2019; Şahin Sak, 2014; Yıldırım vd., 2012; & 6 \\
& Yıldızbaş \& Aslıyüksek, 2016; Zembat vd., 2019 & \\
\hline Beceri & Buldur, 2019; Çakır vd., 2019; Dereli, 2017; Güven vd., 2020; Kayılı \& Arı, & 10 \\
& 2016; Kayılı vd., 2009 ; Kayılı, 2016a;Temel vd., 2016; Yıldız \& Çağdaş, \\
& 2019; Yıldızbaş \& Aslıyüksek, 2016 & 3 \\
\hline Gelişim & Aral vd., 2015; Aydoğan, 2016; Dereli, 2017 & 2 \\
\hline Kavram & Toran \& Temel, 2014; Yüksek Usta \& Tezel Şahin, 2019 & 2 \\
\hline farkındalığı/edinimi & & 1 \\
\hline Hazırbulunuşluk & Kayılı \& Arı, 2011; Toran \& Temel, 2014 & 1 \\
\hline Davranış & Yücesan \& Özyürek, 2017 & \\
\hline Yaratıcılık & Noyat vd., 2019 & \\
\hline
\end{tabular}

Tablo 7'ye göre araştırmalardan altısında görüş ve algılar, 10'unda beceri, üçünde gelişim, ikişer tanesinde kavram farkındalığı/edinimi, ilköğretime hazırbulunuşluk, birer çalışmada ise problem davranış ve yaratıcılık konuları incelenmiştir. Araştırmaların bulguları incelendiğinde ise; Montessori eğitiminin çocukların görsel algılama becerilerinde etkili olduğu (Yıldırım vd., 2012; Yıldızbaş \& Aslıyüksek, 2016), Montessori eğitimi almayan çocuklarla karşılaştırıldığında kavram kazanımlarının farklılaştığı (Toran \& Temel, 2014), Montessori eğitiminin çocukların duyguları anlama ve sosyal problemleri çözme yeteneklerini desteklediği (Kayılı \& Arı, 2016), çocukların bilişsel tempoları üzerinde olumlu etkisi olduğu (Kayılı, 2016a), Montessori eğitimi alan çocukların bilimsel süreç becerilerinde gelişme olduğu (Buldur, 2019), Montessori sınıflarında çocukların yaratıcılıklarının geliştiği (Noyat vd., 2019), Montessori destek eğitimi alan annelerin çocuklarının matematik becerilerinin farklılaştığı (Yıldız \& Çağdaş, 2019), Montessori anaokuluna devam eden çocukların devlet okuluna gidenlerden coğrafi kavramlara yönelik daha fazla bilimsel anlayışa sahip oldukları (Yüksek Usta v\& Tezel Şahin, 2019), dil becerilerinin Montessori eğitimi alan çocuklar lehine farklılaştığı (Aydoğan, 2016; Kayılı vd., 2009), Montessori eğitiminin çocukların ilköğretime hazırbulunuşluklarına katkı sağladığı (Kayılı \& Arı, 2011; Toran \& Temel, 2014), Montessori yaklaşımına dayalı eğitimin çocukların gelişim alanlarına olumlu etkisi olduğu (Aral vd., 2015), çocukların Montessori eğitimine devam süreleri arttıkça görsel algı becerilerinin arttığı (Temel vd., 2016), Montessori eğitiminin motor becerilerini geliştirdiği (Yıldızbaş \& Aslıyüksek, 2016), Montessori eğitiminin çocukların psiko-sosyal gelişimlerinde ve sosyal problem çözme becerilerinde etkili olduğu (Dereli, 2017), Montessori eğitiminin çocukların sudoku çözme becerilerinde etkili olduğu (Güven vd., 2020) sonuçlarına ulaşılmıştır. Bulgular çalışmaların görsel algı, bilişsel (Kavram, matematik, hazırbulunuşluk vb.) ve sosyal gelişim üzerine yoğunlaştığına dikkat çekmiştir.

Okul öncesi öğretmenleriyle yapılan araştırmada ise öğretmenlerin en çok Montessori Yaklaşımı hakkında bilgi sahibi oldukları belirlenmiştir (Zembat vd., 2019). Montessori öğretmenleri yaklaşımı içselleştirdiklerini ve yaklaşım doğru uygulandığında eleştirilerin yersiz olduğunu belirtmiştir (Atlı vd., 2016). Öğretmen adaylarıyla yapılan araştırmada adaylar düzenli sınıf ortamı, gerçek materyallerin kullanımı ve yaklaşımın çocukta özdenetim becerisini kazandırdığını belirtirken adayların yarısı yaklaşımın Türkiye'de uygulanabilir olmadığını düşündüklerini belirtmişlerdir (Şahin Sak, 2014). Ayrıca Montessori temelli STEM etkinliklerinin öğretmen adaylarının yaratıcılık becerilerini olumlu yönde etkilediği (Çakır vd., 2019) belirlenmiştir. 
Kıran, Macun, Argın \& Ulutaş - Çukurova Üniversitesi Eğitim Fakültesi Dergisi, 50(2), 2021, 1154-1183

Son olarak ebeveynler Montessori yaklaşımını çağdaş bir yaklaşım olarak gördükleri için tercih ettiklerini, eğitimin içeriğinden memnun olduklarını ve eğitimin çocuklarını hayata hazırladığını düşündüklerini ifade etmişlerdir (Bozkurt vd., 2019).

\section{Tartışma ve Öneriler}

Çalışma kapsamında Montessori yöntemi üzerine Türkiye'de yapılan çalışmaların sistematik derleme ile incelenmesi amaçlanmıştır. Çalışma kapsamında 22 araştırma makalesi incelenmiştir. İncelenen çalışmalardan nicel araştırma yöntemleri kullanılan (iki yarı deneysel, iki boylamsal, bir ilişkisel tarama, bir tarama ve 10 deneysel) 15 çalışma bulunmaktadır. Nitel araştırma yöntemi kullanılan (iki olgubilim ve dört deseni belirtilmemiş) altı makale ve karma araştırma yöntemi kullanan bir makale bulunmaktadır. İncelenen çalışmaların örneklemleri çocuk, öğretmen, öğretmen adayı ve aile olmak üzere dört başlık altında toplanmıştır. Programın hedef kitlesinin çocuklar olmasına bağlı olarak yapılan çalışmaların daha çok çocuklar üzerine yoğunlaştığı söylenebilir. Ancak okul öncesi eğitimde aile ve öğretmenin bakış açısı da programın uygulanışında karşılaşılan sorunların ortaya konulması bakımından katkı sağlayacaktır. Sonraki çalışmalarda aile ve öğretmen katılımı göz önünde bulundurulabilir, çocuk, öğretmen ve ebeveyn boyutu birlikte değerlendirilebilir.

Yapılan çalışmalardan örneklemi en yüksek olanlar Dereli'nin (2017) 160 çocukla yaptığı ve Güven, Gültekin \& Dedeoğlu'nun (2020) 118 çocuk ile yaptığı çalışmalardır. Diğer çalışmaların ise örneklem sayıları ise 9 ile 93 arasında değişmektedir. Ülkemizde Montessori yöntemini felsefesine uygun olarak uygulayan okul sayısının az olması çalışma grubuna alınacak katılımcıların sayısını sınırlandırmaktadır. Dolayısıyla yapılacak çalışmalarda katılımcı sayısının sınırlılığı göz önünde bulundurulmalı, çalışmaya alınacak okulun Montessori programının ilkelerini ne kadar benimsediği dikkate alınmalıdır.

Araştırmada incelenen 22 makaleden 16'sında geçerlik ve güvenirliği yapılmış olan bir ölçek veya test kullanıldığı, beş çalışmada görüşme formu ve bir çalışmada ise gözlem raporu kullanıldığı belirlenmiştir. $\mathrm{Bu}$ çalışmalara araştırma yöntemi açısından bakıldığında nitel olan altı çalışmanın beşinde yarı yapılandırılmış görüşme formu, birer çalışmada ise gözlem formu ve yansıtma raporu kullanıldığı görülmüştür. Nicel araştırma yöntemi kullanan çalışmaların tümünde geçerliği ve güvenirliği yüksek olan ölçekler kullanıldığı dikkati çekmiş, karma olan bir çalışmada ise yarı yapılandırılmış gözlem formu kullanıldığı belirlenmiştir. Programa ilişkin çıktıları veya ilişkileri ortaya koymak amacıyla karma çalışmalara yönelinmesi daha detaylı bulguya ulaşmayı sağlayacaktır.

Yapılan çalışmaların çoğunluğunun nicel çalışma olması kullanılan ölçeklerden hareketle sonuç odaklı çalışmaların yapıldığı şeklinde yorumlanabilir. Incelenen çalışmaların hiçbirinde süreç odaklı değerlendirmenin yapıldığına ilişkin bulgu elde edilememiştir. Oysaki Montessori eğitim felsefesi sonuç değil süreç odaklı bir eğitimi desteklemektedir (Lillard, 2019; Temel \& Toran, 2019). Çünkü Montessori yönteminde çocuğun öğrenme motivasyonunun sürekliliği amaçlanmaktadır (Kuşçu, Bozdaş \& Yıldırım Doğru, 2014). Dolayısıyla Montessori çalışmalarında sürece yönelik değerlendirmenin ortaya konulması gerekir. Örneğin öğretmenin gözlem sürecinde neler yaptığı, kayıtlarının içeriği, akran öğrenmesinde çocukların etkileşimi gibi birçok unsur süreç değerlendirmede daha açık ortaya konacak, Montessori yönteminin özellikleri daha gözlemlenebilir olacaktır.

Yapılan çalışmada Montessori eğitimine dair çalışmaların 2019 (n=7) ve 2016 (n=5) yıllarında diğer yıllara oranla daha fazla olduğu görülmüştür. Yurt içinde Kayılı (2016b) yaptığı bir derleme çalışmasında $2006(n=6), 2011(n=5)$ ve $2012(n=5)$ yıllarında daha fazla çalışmanın olduğunu belirtmiştir. Yabancı alanyazın incelendiğinde ise Culclasure, Daoust, ve Zoll (2019) çalışmalarında 2017 ( $n=6)$ yılında çalışmaların yoğunlaştığını belirtmiştir. Dolayısıyla Montessori eğitimi üzerine yapılan çalışmalarda son yıllarda bir artış yaşandığı görülmüştür. Bu durum çocuk merkezli programlara olan ilgiden kaynaklanabildiği gibi yöntemin yaygınlaşmasından da kaynaklanmaktadır. Nitekim Danişman (2012) çalışmasında çocuk merkezli eğitim yaklaşımı kullanan okulların popülerleştiğini ve bu yaklaşımlar arasında da en fazla Montessori yaklaşımının tercih edildiğini belirtmiştir. Bu çerçevede bakıldığında gelecekte Montessori ile ilgili çalışmalarda çalışma grubunun oluşturulmasında kolaylık olabileceği gibi 
Kıran, Macun, Argın \& Ulutaş - Çukurova Üniversitesi Eğitim Fakültesi Dergisi, 50(2), 2021, 1154-1183

okullar arası uygulama farklılıklarının ortaya konulması bakımından da araştırmacılara veri sağlayabilecektir.

Yapılan çalışmada incelenen makalelerde örneklemi çocuk olan çalışmaların ikisinde Montessori eğitimi ile devlet okullarında eğitim alan, ikisinde ise Montessori eğitimi alan ve almayan çocuklar çeşitli beceriler açısından karşılaştırılmıştır. Çocuk örneklemli 13 çalışmada ise Montessori eğitiminin çocukların belirli bir gelişim alanına veya düzeyine olan etkisi incelenmiştir. Hâlbuki Montessori eğitim yaklaşımı çocukların bütüncül gelişimlerini desteklemeyi amaçlamaktadır. Yapılan çalışmaların dördünde görsel algı ve dikkat, üçünde bilişsel gelişim, ikisinde psiko-sosyal gelişim, ikisinde kavram edinim düzeyleri, sırasıyla birer çalışmada ise ilköğretime hazır olma durumları, motor gelişim, tüm gelişim alanları, yaratıcılık, öz bakım becerileri incelenmiştir. Çalışmaların daha çok görsel algı, bilişsel, dil ve sosyal gelişim üzerine yoğunlaştığı görülmüştür. Yapılacak çalışmaların belirli gelişim alanlarına odaklanmak yerine tüm gelişim alanlarını karşılaştırılması ve Türkiye'de uygulanan Montessori eğitiminin tüm yönleriyle değerlendirilmesi mümkün olabilecektir.

Sonuç olarak, araştırma bulguları Montessori yönteminin çocuklar ve gelişimleri üzerindeki çıktısına odaklı çalışmaların çoğunluğuna, süreci irdeleyen çalışmaların gerekliliğine, nitel veya karma çalışmaların azlığına, çalışma grubuna ulaşmanın sınırlılığına dikkat çekmiştir. Araştırmada Türkiye'de yapılan çalışmaların sistematik derleme ile objektif olarak ortaya konulmasına, araştırmacılara Montessori yöntemi ile ilgili kanıtlar sunulmasına ve yeni çalışma önerileri ortaya konulmasına çalışılmıştır. Sonraki çalışmalarda sistematik analiz güncellenebilir, dahil etme kriterleri değiştirilerek farklı çalışma grubuna ulaşılabilir. Ayrıca yabancı literatür de ele alınabilir, böylelikle Montessori yöntemine ilişkin global yorum elde edilebilir.

Yayın Etiği: Bu araştırmada "Yükseköğretim Kurumları Bilimsel Araştırma ve Yayın Etiği Yönergesi" kapsamındaki tüm kurallara uyulmuştur. Yönergenin ikinci bölümü olan "Bilimsel Araştırma ve Yayın Etiğine Aykırı Eylemler" başlığı altında belirtilen eylemlerden hiçbiri gerçekleştirilmemiştir.

\section{References}

Alkan, V. (2017). Bir sistematik derleme çalışması: 'Öğretmenlik uygulaması'. YILDIZ Journal of Educational Research, 2 (1), 1-23.

Aral, N., Yıldız Bıçakcı, M., Yurteri Tiryaki, A., Çetin Sultanoğlu, S., \& Şahin, S. (2015). Montessori eğitiminin çocukların gelişimine etkisinin incelenmesi. Hacettepe Üniversitesi Eğitim Bilimleri Enstitüsü Eğitim Araştırmaları Dergisi, 1(1), 32-52.

Atlı, S., Korkmaz, A. M., Taştepe, T., \& Akyol, A. K. (2016). Views on Montessori approach by teachers serving at schools applying the Montessori approach. Eğitim Araştırmaları-Eurasian Journal of Educational Research, 2016(66), 123-138.

Aydoğan, Y. (2016). Examination of the affect of Montessori education on language development of preschool children. Academic Research International. 7(5), 112-119.

Bereczki, E. O., \& Kárpáti, A. (2018). Teachers' beliefs about creativity and its nurture: A systematic review of the recent research literature. Educational Research Review, 23, 25-56.

Bettany-Saltikov, J. (2012). How to do a Systematic Literature Review in Nursing: A step-by-step guide. McGraw-Hill Education.

Bozkurt, E., Kölemen, E. B., Abanoz, T., \& Ulutaş, i. (2019). Çocukları Montessori eğitimi alan ebeveynlerin “Montessori eğitimi” algısı. The Journal of Academic Social Science, 7(92), 239-251.

Buldur, A. (2019). Montessori eğitim programına devam eden okul öncesi dönem çocuklarının bilimsel süreç becerilerindeki değişimin incelenmesi. Cumhuriyet Uluslararası Eğitim Dergisi, 8(4), 1172-1186. 
Kıran, Macun, Argın \& Ulutaş - Çukurova Üniversitesi Eğitim Fakültesi Dergisi, 50(2), 2021, 1154-1183

Carol, T., Jill, H., ve Kate, L.-L. (2017). Systematic reviews. In R. Coe, M. Waring, L. V. Hedges, ve J. Arthur (Eds.), Research Methods ve Methodologies in Education (2nd Edt, pp. 448-482). United Kingdom: SAGE Publications.

Cossentino, J.M. (2006). Big Worg: goodness, vacation and engagement in the Montessori method. The Ontario Institute for Studies in Education of the University of Toronto. Curriculum Inquiry, 36(1), 6392.

Crompton, H., Burke, D., \& Gregory, K. H. (2017). The use of mobile learning in PK-12 education: A systematic review. Computers \& Education, 110, 51-63.

Culclasure, B. T., Daoust, C. J., Cote, S. M., \& Zoll, S. (2019). Designing a logic model to inform montessori research. Journal of Montessori Research, 5(1), 35-49.

Çakır, Z., Altun Yalçın, S., \& Yalçın, P. (2019). Montessori yaklaşım temelli stem etkinliklerinin okul öncesi öğretmen adaylarının yaratıcılık becerilerine etkisi. Uluslararası Bilimsel Araştırmalar Dergisi (IBAD), $4(2), 392-409$.

Danişman, Ş. (2012). Montessori yaklaşımına genel bir bakış ve eğitim ortamının düzenlenmesi. Journal of Policy, 1(2), 85-113.

Dereli, E. (2017). Montessori eğitim programının çocukların psikososyal gelişimlerine ve sosyal problem çözme becerilerine etkisinin incelenmesi. Journal of Kırşehir Education Faculty, 18(2), 135-153.

Güven, Y., Gültekin, C., \& Dedeoğlu, A. B. (2020). Comparison of sudoku solving skills of preschool children enrolled in the Montessori approach and the national education programs. Journal of Education and Training Studies. 8(3), 32-47.

Kayılı, G. (2015). Sosyal beceri eğitimi programı ile desteklenmiş Montessori yönteminin anaokulu çocuklarının duyguları anlama ve sosyal problem çözme becerilerine etkisi. Yayınlanmamış doktora tezi. Selçuk Üniversitesi, Konya, Türkiye.

Kayılı, G. (2016a). The effect of Montessori method on cognitive tempo of kindergarten children. Early Child Development and Care, 188(3), 327-335.

Kayılı, G. (2016b). Türkiye'deki Montessorı yöntemi ile ilgili araştırmalar: 2000-2016 yılları arasındaki araştırma yayınlarının incelenmesi. 1. INES(International Academıc Research Congress), 1345-1353, Antalya.

Kayılı, G., \& Arı, R. (2011). Examination of the effects of the Montessori method on preschool children's readiness to primary education. Educational Sciences: Theory and Practice, 11(4), 2104-2109.

Kayılı, G., Koçyiğit, S., \& Erbay, F. (2009). Montessori yönteminin beş-altı yaş çocuklarının alıcı dil gelişimine etkisinin incelenmesi. Selçuk Üniversitesi Türkiyat Araştırmaları Dergisi, 1(26), 347-355.

Kusumawardani, L., Nani, D., \& Sulistiani, S. (2020). Improving gross motor skill development through the Montessori method in children aged 3-5 years. Sri Lanka Journal of Child Health, 49(4), 347352.Lillard, A. S. (2005). Montessori: the science behind the genius. New York: Oxford University Press.

Kuşçu, Ö., Bozdaş, Y., \& Doğru, S. S. Y. (2014). Montessori eğitiminin çocuklarda sorumluluk alma, sırasını bekleme, başladığı işi bitirme becerisine etkisinin değerlendirilmesi. Değerler Eğitimi Dergisi, 12(27), 307-322.

Lillard, A. S. (2005). Montessori: The science behind the genius. Oxford University Press.

Lillard, A. S. (2012). Preschool children's development in classic Montessori, supplemented Montessori, and conventional programs. Journal of School Psychology 50: 379-401.

Lillard, A. S. (2019). Shunned and admired: Montessori, self-determination, and a case for radical school reform. Educational Psychology Review 31:939-965.

Lillard, A. S., Heise, M. J., Richey, E. M., Tong, X., Hard, A. \& Bray, P. M. (2017). Montessori preschool elevates and equalizes child outcomes: a longitudinal study. Frontiers in Psychology, 8: 1-19. 
Kıran, Macun, Argın \& Ulutaş - Çukurova Üniversitesi Eğitim Fakültesi Dergisi, 50(2), 2021, 1154-1183

Miezitis, S. (1971). The Montessori method: some recent research. Interchange A Quarterly Review of Education, 2(2), 41-59.

Millar, J. (2004). 'Systematic Reviews for Policy Analysis', S. Becker ve A. Byrman (ed.), Understanding Research for Social Policy and Practice: Themes, Methods and Approaches içinde, Bristol: Policy Press.

Money, C. G. (2000). An Introduction to Dewey, Montessori, Piaget, and Vygotsky. Manchester: Redleaf Press.

Montessori, M. (1966). The secret of childhood. Ballantine Books.

Neubert, A. B. (1973). A way of learning: a Montessori manual. Cincinnati: Xavier University Press.

Noyat, Ş., Karahan, Ç. İ., \& Alakuş, A. O. (2019). Okul öncesi Montessori eğitimi yaklaşımında sanat eğitimi ve yaratıcılık. Dicle Üniversitesi Ziya Gökalp Eğitim Fakültesi Dergisi, 34, 48-59.

Oğuz, V., \& Köksal Akyol, A. (2006). Çocuk eğitiminde Montessori yaklaşımı. Çukurova Üniversitesi Sosyal Bilimler Enstitüsü Dergisi, 15(1), 243-256.

Şahin Sak, i. (2015). Okul öncesi öğretmen adaylarının Montessori ve Reggio Emilia yaklaşımları ile ilgili görüşleri. Inönü Üniversitesi Eğitim Fakültesi Dergisi, 15(3), 1-20.

Taner Derman, M., Sadioğlu, Ö., Bağçeli Kahraman, P., \& Onur Sezer, G. (2010). Okul öncesi eğitimde montessori metodu. H. A. Başal (Ed.), Okul öncesi eğitimde uygulanan farklı modeller içinde (ss. 4797). Bursa: Dora.

Temel, Z. F. \& Toran, M. (2019). Montessori eğitim yöntemi. Z. F. Temel (Ed.), Erken çocukluk eğitiminde yaklaşımlar ve programlar içinde (ss. 151-202). Vize.

Temel, Z. F., Kaynak, B., Paslı, H., Demir, H., \& Çemrek, B. (2016). Montessori eğitim kurumlarındaki çocukların görsel algı ve çizim becerileri arasındaki ilişkinin incelenmesi. Kastamonu Eğitim Dergisi, 24(5), 2595-2608.

The PRISMA Statement. (2020). PRISMA Statement. http://www.prismastatement.org/PRISMAStatement/

Toran, M., \& Temel, Z. F. (2014). Montessori yaklaşımın çocukların kavram edinimi üzerindeki etkisinin incelenmesi. Elementary Education Online,13(1), 223-234.

Torrence, M., \& Chattin-McNichols, J. (2005). Montessori education today. J. L. Roopnarine \& J. E. Johnson (Edt.), Approaches to early childhood education in (pp. 235-250). New Jersey: Pearson.

Yıldırım, S., Akman, B., \& Alabay, E. (2012). Okul öncesi dönem çocuklarına sunulan Montessori ve mandala eğitiminin görsel algılama davranışlarına etkisinin incelenmesi. Dokuz Eylül Üniversitesi Buca Eğitim Fakültesi Dergisi, 32, 92-103.

Yıldız, F. Ü., \& Çağdaş, A. (2019). The effects of Montessori training program for mothers on mathematics and daily living skills of 4-5 year-old Montessori children. Erken Çocukluk Çalışmaları Dergisi,3(2), 278-299.

Yıldızbaş, F., \& Aslıyüksek, M. (2016). Montessori eğitiminin 4-5 yaş çocuklarının motor beceri, görsel algı ve bellek, el-göz koordinasyonu ile küçük kas becerilerinin gelişimine etkisinin incelenmesi. Turkish Studies (Elektronik), 11(3), 2407-2426.

Yiğit, T. (2008). Okul öncesi eğitim kurumlarında Montessori ve geleneksel öğretim yöntemleri alan çocukların sayı kavramını kazanma davranışlarının karşılaştırılması. Yayımlanmamış yüksek lisans tezi. Selçuk Üniversitesi Sosyal Bilimler Enstitüsü, Konya.

Yücesan, Y., \& Özyürek, A. (2017). Montessori eğitimi alan ve almayan okul öncesi dönem çocuklarının problem ve davranışlarının incelenmesi. LAÜ Sosyal Bilimler Dergisi, 8(2), 215-226.

Yüksek Usta, S., \& Tezel Şahin, F. (2019). Çocukların coğrafi farkındalıkları: Montessori eğitiminin yansımaları. Gazi Üniversitesi Gazi Eğitim Fakültesi Dergisi, 39(1), 1-35. 
Kıran, Macun, Argın \& Ulutaş - Çukurova Üniversitesi Eğitim Fakültesi Dergisi, 50(2), 2021, 1154-1183

Zembat, R., Günşen, G., \& Gök Çolak, F. (2019). Okul öncesi öğretmenlerinin erken çocukluk eğitiminde uygulanan farklı yaklaşımlar hakkındaki bilişsel haritaları. Trakya Üniversitesi Sosyal Bilimler Dergisi, 21(Ek), 1-19. 